\title{
Chemical Investigation of Active Lipopeptides Produced by Bacillus subtillis natto and the Application in Animal Feed
}

\author{
Mohamed Osman Hassan ${ }^{1,2}$, Di Zhang ${ }^{1}$, Abdul Razak Monto ${ }^{1}$, Haroon Elrasheid Tahir ${ }^{1}$, \\ Garba Betchem $^{1}$, Sulafa B. H. Hashim ${ }^{1}$, Marcellinus Zekruma ${ }^{1}$, Ngouana Moffo A. Ivane $^{1}$, ShuaiLiu ${ }^{2 *}$, \\ Yuping $\mathrm{Zhao}^{2 *}$, Xiaobo Zoua ${ }^{1 *}$ \\ ${ }^{1}$ School of Food and Biological Engineering, Jiangsu University, Zhenjiang, 212013, China
}

${ }^{2}$ School of life Sceince and Chemical Engineering, Huaiyin Institute of Technology Meicheng Rd, Huai'an 223003, Jiangsu, China

Corresponding Author E - mail address: osmann20200[at]gmail.com

\begin{abstract}
Surfactin is a highly effective surfactant produced by bacteria, and commonly used as an antibiotic or probiotic. Due to its low UV absorption, it is not easy to detect this type of lipopeptides by HPLC directly, so we use thin layer chromatography combined with ninhyrin reaction, and various column chromatography to identify and purify surfactins from Bacillus subtilis. Secondly, the antibacterial effect of lipopeptide was examined, with the purpose to evaluate the potential to replace antibiotics in feed. Third, since Aspergillusniger has a strong enzyme production system, such as amylase and cellulose, the co - cultivation of Aspergillusniger and Bacillus subtilis on feed could increase the available nutrition. Both microorganisms are safe and are allowed to be used in feed fermentation, but the accumulation of secondary metabolites will be different from the solo fermentation, especially the formation of sufactins. So, the co - cultivation of Aspergillusniger and Bacillus subtilis on animal feed was studied.
\end{abstract}

Keywords: Sufactins, Bacillus subtillis, Aspergillusniger, fermented feed.

\section{Introduction of Lipopeptides}

A lipopeptide is a molecule containing a hydrophobic chain of fatty acids and a hydrophilic cyclic peptide, or a class of self - organizing molecules capable of forming peptide functionalized nanostructures. They are amphiphilic and usually include one or more peptidyl linked by a liquid chain. Bacteria express these molecules, and some lipopeptides are used as antibiotics.

The Bacillussp. bacteria are considered as an effective microbial factory for large - scale production of biologically active molecules of this type. Bacillussp. bacteriacan produce three families of lipopeptides: surfactin, iturin, and fengycin.

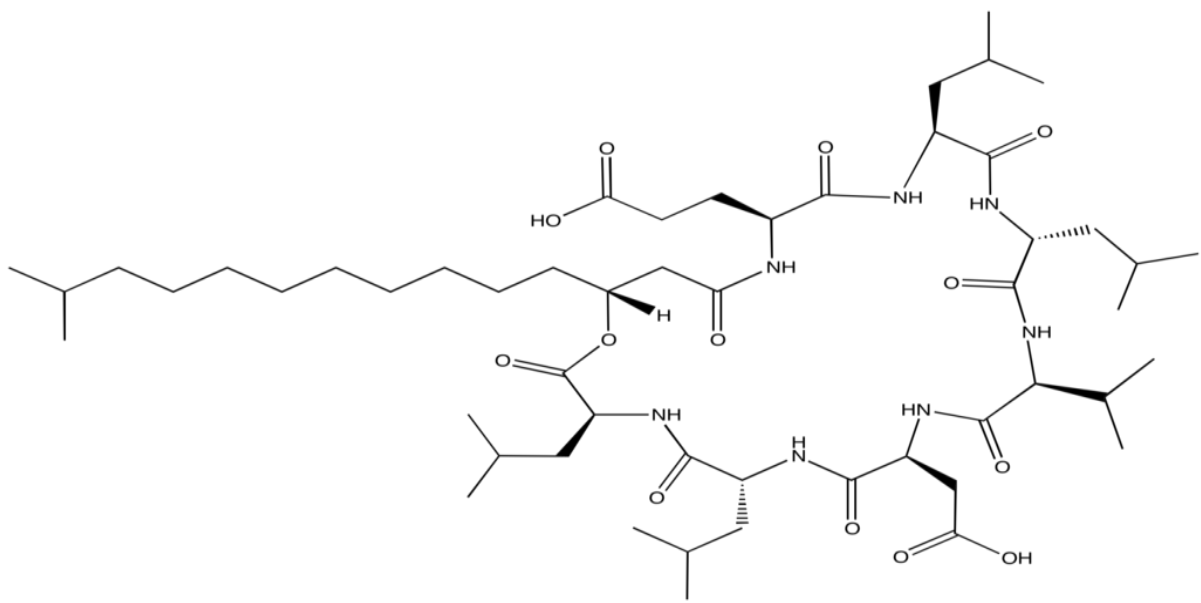

Figure 1: Structure of lipopeptite

Surfactin is a highly effective surfactant commonly used as an antibiotic or probiotic. It is a bacterial cyclic lipopeptide and its amphipathic nature helps the substance survive in both hydrophilic and hydrophobic environments. This is an antibiotic produced by Bacillus, a gram - positive bacterium.
In addition, cyclic lipopeptides contain chain fatty acids related to amino acids, and the derivatives of each group of compounds come from different amino acid components. 


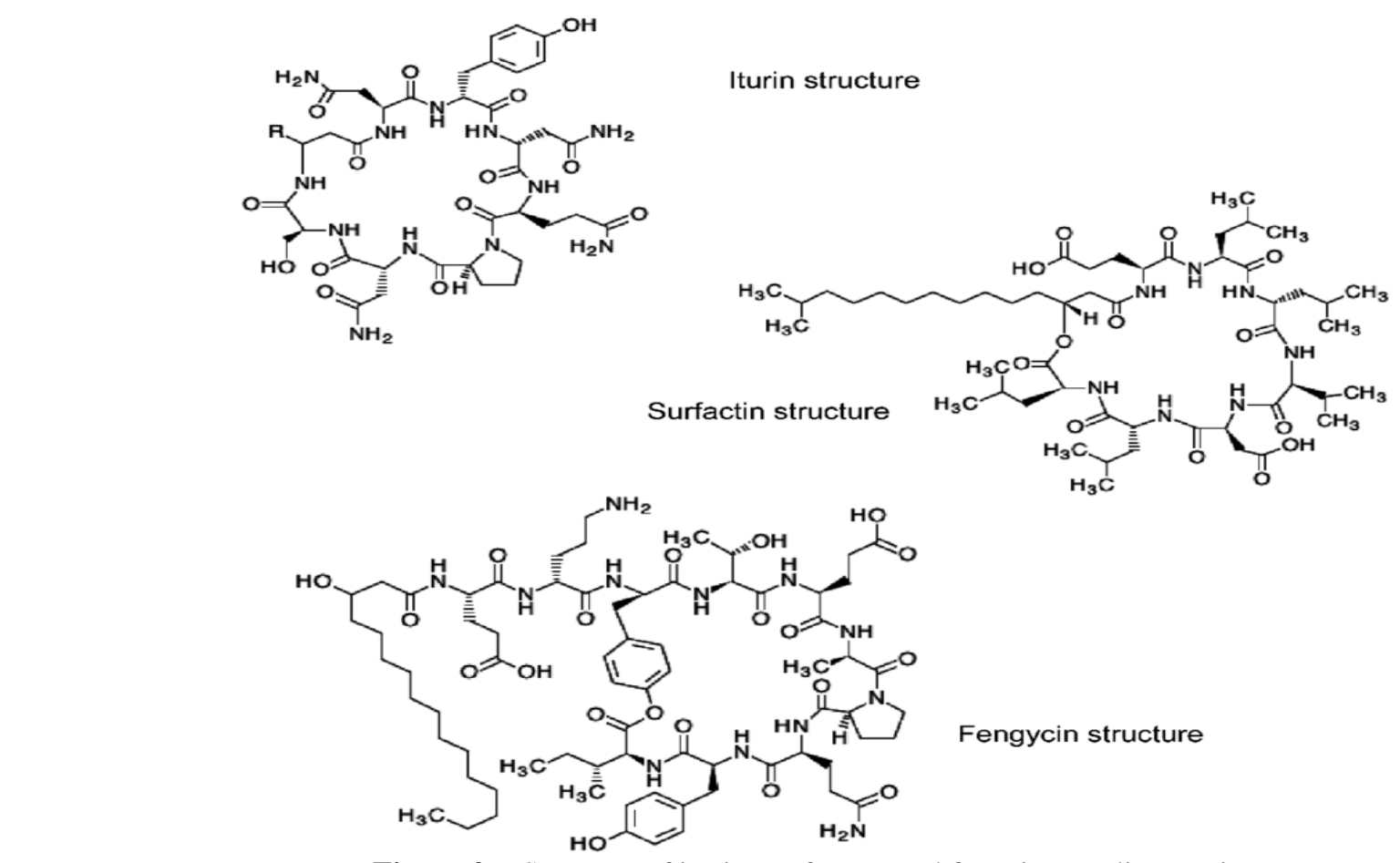

Figure 2: . Structure of iturin, surfactant and fenycin type lipopeptite

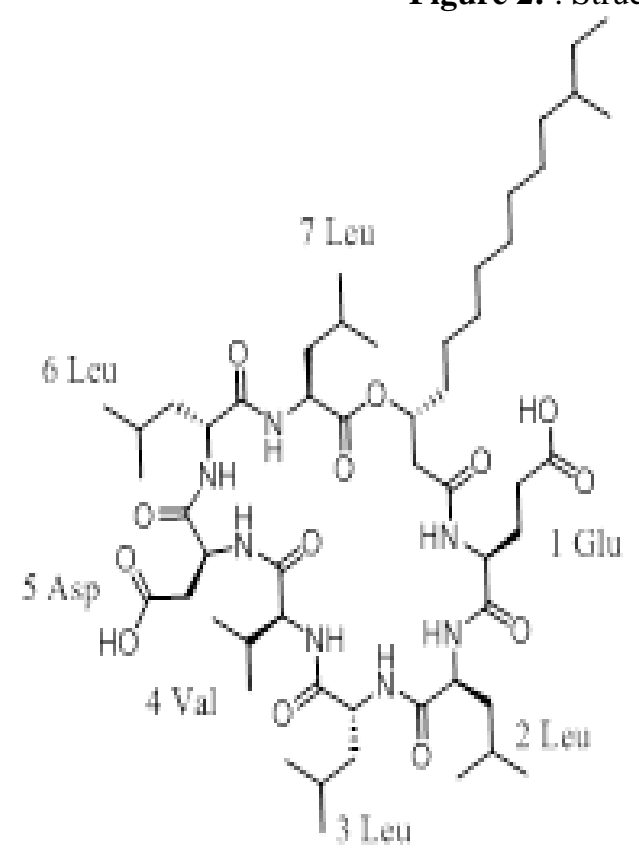

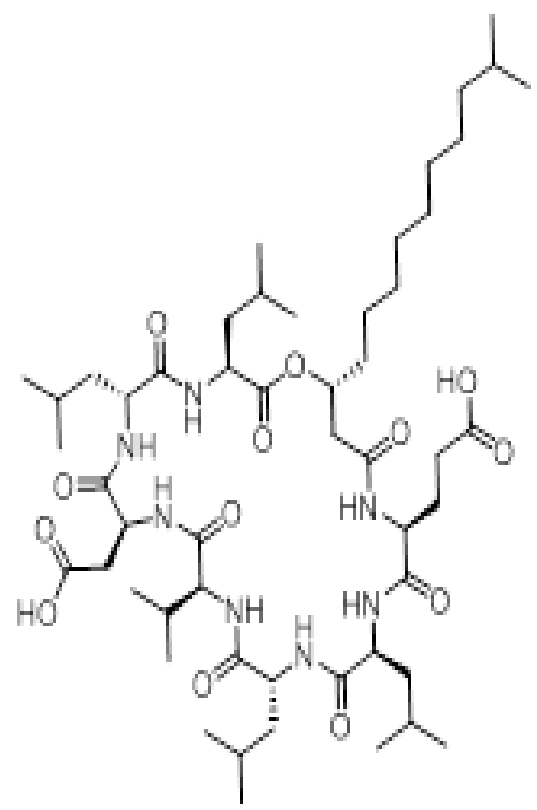

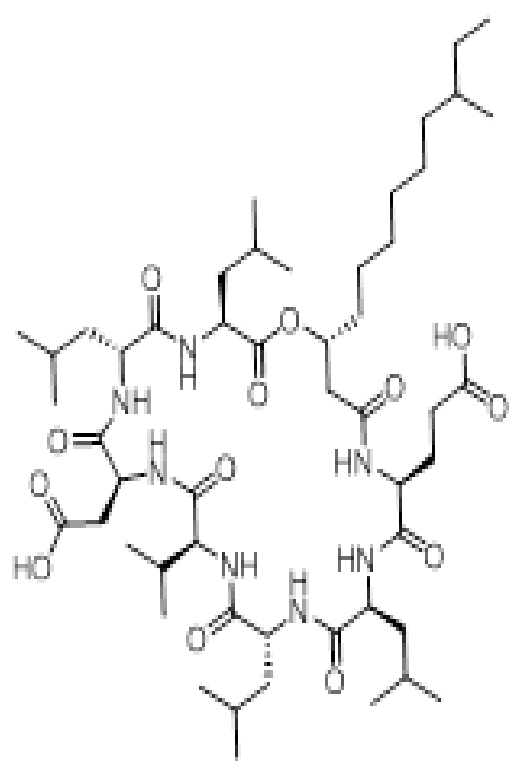

Figure 2.1: Structure of surfactin

The lipoprotein of the lipobacterium Bacillus is a small metabolite, which contains a cyclic structure formed by $\beta$ hydroxy fatty acids having multiple amino acids which include13 19 carbon atoms and2 4 amino acids. These lipopeptides exhibit a variety of biological activities, including biofilm interactions, anti - fungal, anti inflammatory, anti - tumor and anti - viral.

Antibiotics are antibacterial substances that are active against bacteria. Although antibiotics are the most important antibacterial agents against infections, they can also kill beneficial bacteria, so the abuse of antibiotics in the feed industry result drug resistance, such as MDRO. Probiotics like lipopeptides can form a balance of microbiota in the intestine, thereby inhibiting the harmful microorganisms.
Future probiotics may replace antibiotics in the feed industry.

Lipopeptides usually considered as small compounds of secondary metabolites which can be synthesized by various microorganisms. Structurally, lipopeptides contain fatty acids and a hydrophobic chain of hydrophilic cyclic peptides. According to the structure of the cyclic peptides, Bacillus lipopeptides mainlydistributed into three families such as detergent, tocomycin and iturin. Owing to their amphiphilic structure, lipopeptides have different biological activities, such as antibacterial, antifungal, antiviral and antitumor activities, which makes them very useful and interesting for the development of useful things for pharmaceutical, agricultural, chemical, and biomedical applications. (Jiang et al., 2014).

\section{Volume 10 Issue 10, October 2021} www.ijsr.net 


\section{International Journal of Science and Research (IJSR) ISSN: 2319-7064 \\ SJIF (2020): 7.803}

In addition to low nutritional requirements, rapid growth, human and animal safety, as well as high antibacterial activity. Bacillus subtilis can also be considered as one of the most widely used microorganisms in industrial production of the active lipopeptide. The use of Bacillus subtilis have also attained enormous attention and found very fruitful in agriculture industry, food industry, medicine and feed production, as it can secrete various enzymes and antibiotics. Superficial actin and tocomycin are inducers that induce resistance in plant systems (Onega et al., 2007). Some lipopeptides from Bacillus subtilis can effectively hinder the development of microorganisms in food which make them good candidate to be used as biological preservatives for the preservation of food. (Meena and Kanwar2015).

Feeding weaned piglets with lipopeptidefrom Bacillus subtiliscan promote the growth of intestinal bacteria, enhance the systemic immunity and provide better intestinal micro - ecological environment (Dehghan - Noude et al., 2005). Lipopeptides have wide spread applications in the area of antiviral drugs, antitumor drugs, (Myoungseok et al., 2009) thrombolytic agents, and oral adjuvants (Pan et al., 2014). Besides, they can also play an effective role as an auxiliary tool for the hepatitis B vaccine and the treatment of diabetes (superior, 2014)

\subsection{General Objectives}

The first objective is to develop detection methods of lipopeptide and suitable methods of extraction and purification for the biosurfactant.

The third objective is to examine bioactivity of the biosurfactant as antibacterial agent for the application in the feed industry.

The final objective is to describe potential advantage effectives of cocultivation of Bacillus subtilis and Aspergillusniger, and the influence on the accumulation of secondary metabolites.

\subsection{Types and structures of Bacillusli popeptides}

Liposomal lipoproteins are generally distributed into three categories based on specific chains of peptides and fatty acids, surfactants, itulin, and tocaine.

Surfactant proteins were first identified from the Bacillus subtilis culture medium (Arima et al., 1968). Surface actin is a very effective surfactant. Ordinary surfactants contain a peptide with a sequence of seven amino acids: (L -) Glu - (L -) Leu - (D -) Leu - (L -) Val - (L -) Asp - . (D) Lei (L -) Leu. This peptide is bound to a $\beta$ - hydroxy fatty acid containing 13 to 15 carbon atoms by lactone bonding. The identity of amino acids, the number of $\mathrm{C}$ atoms in the fatty acid chain, and the structural composition of different homologous surfactants also differ in the second, fourth, and seventh positions. The seventh position is the serum heptapeptide, which is bound by a fatty acid amino acid from a fatty acid chain containing 14 to 17 carbon atoms (Pipox et al., 1999).

Fengycin is another anti - fungal Lipopeptide complex produced by Bacillus. In addition to hydroxylated fatty acids with 15 to 19 carbon atoms, phenols are also present in the Glu - (D -) Orn - (L -) Tyr - (D -) Thr - (L -) Glu peptide chain. - (D -) ele (Val) - (L -) Pro - (L -) Gln - (D -) Tyr - (L -) - Ile. Tyr at position 3 attaches to Ile at position 10 to form a circular peptide through the lactone bond. The two main types of actinomycin, actinomycin A and B, differ in the identity of the sixth amino acid (Schneider et al., 2012; Tanjal.2014).

Lipopeptides have been considered as small compounds which were usually synthesized by various microorganisms and are structurally secondary to metabolites. Lipopeptide contains a chain of hydrophobic fatty acids and a hydrophilic annular peptide. According to this structure, cyclic surfactin, phenytoin, itorine and lipopeptide can be divided into three families. Its amphiphilic structural lipopeptide has a variety of biological activities such as antifungal, antibacterial, antitumor and antiviral activities, making it very useful for the development of tools in the chemical, agricultural, and pharmaceutical industries. I am interested in other antiviral and anti - tumor drugs that can be used to treat diabetes and hepatitis B vaccines.

Bacillus subtilis is the most widely used lipopeptide active microorganism in the industry. Bacillus subtilis enzymes and antibiotics can be used in agriculture, food and medicine. This nutrient can be used as a biological preservative to prevent food spoilage.

Many crops are damaged by different pathogens including bacteria, fungi, and yeasts, which are causing financial losses to farmers.

Representatives of the genus Bacillus are considered to be plants that produce active biological molecules that inhibit the growth potential of plant pathogens. Plant diseases are a new warning to worldwide food security. Several antibacterial agents, which are currently present in agriculture are highly toxic and non - degradable, resulting in long - term environmental pollution. In addition, most plant pathogens are resistant to antibacterial agents.

Lipopeptides have been tested as multi - purpose weapons effective against a variety of plant pathogens. Three families of lipolytic bacteria, surfactants, uracil, and phenylalanine, are resistant to a variety of plant pathogens, including bacteria, fungi, and doomists. Iturin and phengite have antifungal activity, surfactant has a wide range of effective antibacterial activity and can also be used as a cache larva Interestingly, lipopeptides are biological molecules and are environmentally friendly.

Soy products are nutritious not only because of their high protein and fat content, but also because of their phytochemical components, especially flavonoids (Kishida et al., 2008). Soy is toxic without treatment and needs to be processed. Therefore, extracting oil from soybean shells containing about $48 \%$ crude protein can form soy flour. Soy meal also contains many anti - nutritional agents that should be eliminated (Dansford et al., 1989; LI et al., 1990). In the fermentation process, bacterial and fungal strains (mostly Bacillus subtilis and Aspergillusoryzae, respectively) are used. Fermented soybean meal has been reported to have

\section{Volume 10 Issue 10, October 2021 www.ijsr.net}


many benefits, including the breakdown of the microbial proteolytic enzyme soy allergens, and fermented soybean meal has improved nutritional value. Soybeans are used as a probiotic instead of antibiotics because long - standing usage of antibiotics can lead to drug resistance. This is due to the recent limited use of antibiotics for sub therapy in some countries (Tronstand, 1997). Probiotics are very important because the gastrointestinal tract (GIT) can control hundreds of bacterial strains. Some of them are toxic or harmful, such as Salmonella and E. coli.

Fermentation and zinc of soybean by mushroom, Aspergillusoryzae (Feng et al., 2007a, b; liu et al.; 2007), Aspergillusniger (Mathivanan et al., 2006), high phosphorus diet (Ilyas et al., 1995) (Hirabayashi et al., 1998) is also published. Degradation of carbohydrates associated with galactosidase. Bacillus has traditionally been used for bacterial fermentation (Han et al., 2001).

\section{Literature Review}

\subsection{Lipopeptides}

A lipopeptide is a molecule that contains a hydrophobic chain of fatty acids and a hydrophilic cyclic peptide. Most crops are affected and eventually affected by pathogens, such as: mushrooms, bacteria, yeasts and other plant pathogens. Bacterial isolation and identification as Bacillus subtilis, followed by phylogenetic analysis. In this study, Bacillus subtilis lipopeptide is a known molecule that is active against a variety of plant pathogens, such as Aspergillusniger and Fusariumoxysporum. (Dello et. al., 2013).

Lipopeptides are environmentally friendly, biodegradable and stable at high temperatures. These Bacillus subtilis lipopeptides are large enzymes composed of ordered functional units (called ordered modules), which are synthesized by enzyme complexes and catalyze various reactions.

Some properties of lipopeptides are achieved by the sensitive methods of thin layer chromatography and high performance liquid chromatography (HPLC). It is used for purification and partial identification of lipopeptide bioactive molecules.

In the past 15 years, the number of probiotics used in animal husbandry has greatly increased. Probiotics are defined as living microorganisms, as long as they are taken regularly in an appropriate amount, they can benefit the health of the host; after probiotics enter the human body, they can adjust the balance and activity of the gastrointestinal flora. The role of the intestinal flora is the intestine. The basis of Tao steady state. Some antibacterial substances produced by probiotics can inhibit the growth of pathogens in the intestine.

Probiotics can act on the components of the digestive tract of the immune system and protect the host from various antigens in the lumen of the digestive tract. Both natural probiotics and adaptive immunity benefit from exposure to probiotics, since probiotic support for immune function can prevent human diseases in the future.

\subsection{Biological activity}

Due to its diverse structure and composition, the Bacillus lipolytic lipopeptide has amphiphilic properties, and the Bacillus lipophileslipopeptide has three families: surfactant, itulin and phenylalanine.

Surfactin: A very effective surfactant commonly used as an antibiotic. This is a bacterial cyclic lipopeptide with amphiphilic properties, which can help a substance survive both in a hydrophilic and hydrophobic environment. It is an antibiotic produced by Bacillus subtilis (an endospore forming bacterium of gram - positive bacteria).

The structure of iturin, surfactin and fengicin. Cyclic lipopeptides contain chains of fatty acids associated with amino acids. Derivatives of each group of compounds come from different amino acid components (Cao et al. (2010).

\subsubsection{Biofilm Interaction}

Lipopeptides might possess the capability to reduce surface tension and adhesion of interfacial biofilms. In addition, lipopeptides can have the ability to eventually destroy the structure of the membrane by using various mechanisms. Several investigators believe that this is the main mechanism of biological activation of lipopeptides.

As the name suggests, surfactants have an effect which is related to the surface properties. The surfactin is placed inside the lipid layer and dissolved, so that the liquid phase of the phospholipid is dissolved, the monopharyngeal and divalent cations are chlorinated and the membrane is dissolved by forming a channel or mechanism similar to detergent. Change slowly. Some studies have shown that surfactants can form voltage self - determining channels in biofilm by different conducting levels. Moreover, such channels disrupt membrane integrity and permeability of ions such as $\mathrm{K}^{+}$and $\mathrm{Ca}^{2+}$, and mayoriginate rupture of the membrane (Dello et al., 2013).

Bacillus subtilisin matrix can interact with the membrane through groups of sterols. The goal of ergosterol Bacillus subtilis present in sensitive membranes or sensitive fungi is to ensure that Bacillus has resistance to fungi.

Basilomycin L is an effective lipoprotein (etoline) with antifungal activity and is believed to interfere primarily with the formation of membranes. In addition to the permeability of the fungal membrane, it also has antifungal activity.

Deloy's research shows that depending on the molecular ratio, chloramphenicol affects the structure and morphological characteristics of the biofilm. When the penicillin ratio is low, the density of a layer changes,

However, the morphological characteristics of each layer are less affected. Toyomycin dilutes the layer by interacting with the molecular components of the layer. Creatinine can break down lipid sequences at a higher rate (Delo et al., 2005).

Volume 10 Issue 10, October 2021 www.ijsr.net

Licensed Under Creative Commons Attribution CC BY 


\subsubsection{Antifungal activity}

The antifungal activity of lipolytic lipopeptides is particularly important. Recent reports indicate that lipopeptides exhibit antifungal activity at high concentrations, form pores in cell membranes and have low concentrations.

Causes apoptosis. Therefore, lipopeptides can also prevent the formation of cell walls. In addition, they can affect the adhesion of microorganisms by sharing liquid phase interfaces with different polarities and hydrogen bonds. An antifungal product has been found in Bacillus cereus, as an active antifungal surface, and has shown strong antifungal activity against certain important clinical fungi. Ajesh's research shows that this separate surfactant can resist heat, acid and alkalis in 15 minutes when heated to $70{ }^{\circ} \mathrm{C}$. This activity maintains the maximum neutral $\mathrm{pH}$ (Ajesh et al., 2013).

The recently identified WH1 microtoxin, a surfactant, is produced by the liquefaction of starch from Bacillus amyloliquefaciens. The compound inhibits the synthesis of dextran, thereby reducing the synthesis of contact with the fungal cell wall. Classic oxygen, like active oxygen, indicates a specific apoptosis marker, resulting accumulation the ROS, phosphatidylserine (PS) accumulation, DNA strand breaks and caspase - like activity.

Iturin is used against Verticilliumdahliae (cotton carrier Verticillium dahlia). After treatment with guanine, the accumulation of ROS in fungi, the activation of activated mutant protein kinase (MAPK) Hog 1 and cell wall integrity defects were identified. Clearly, oxidative stress and the glucose V glycerol pathway response contribute to Dalia's resistance to itoline. The MAPK pathway may be linked to the sensitivity of this fungus to allergens (Han et al., 2015). Iturine has a strong antifungal activity against the aflatoxin producing bacterium Aspergillusflavus A. For us, parasitic soy products have two common pollutants (Chou et al., 2009).

The antifungal effect of Fangaisin across turbulent membranes (Gonzalez - Jaramillo et al., 2017) leads to apoptosis at low concentrations and necrosis at high concentrations. When fungal cells process fungal cells, the indicators related to apoptosis are increased in a dose dependent manner. These markers include chromatin density, ROS accumulation, possible depolarization of the mitochondrial membrane, PS jet and DNA strand breaks. Fungal cells are destroyed by many important functions, and low - concentration phenytoin treatment comes into play.

\subsubsection{Antitumor activity}

Bacillus lipopeptides have shown anti - tumor activity against specific cancer cells, including destruction and invasion inhibition (Park et al.2013c). The currently reported mechanisms include induction of apoptosis and cessation of the cell cycle Surfactin can inhibit the growth of LoVo cells, a human colon cancer cell line, induce apoptosis activity and delay the cell cycle.

After treatment with surfactant, surfactant kills human breast cancer cell MCF - 7, resulting in the formation of reactive oxygen species (ROS), stable activation of ERK1 / 2 and phosphorylation of JNK (Cao et al. (2010).

\subsubsection{Anti - inflammatory effect}

Multiple studies have shown that surfactants have the ability to block the inflammatory effects of LPS that interact with macrophages. Current proposed mechanisms of anti inflammatory activity include interaction with cytosol.

Phospholipase A2 (PLA2), TLR4 regulation and cell signaling pathway of nuclear factor $\kappa B$ cells $(N F-\kappa B)$, lipophosphate (LTA) inhibits the activation of NF $-\kappa B$, signal transducers and transcription activators (STAT - 1) Increased phosphorylation of STAT - 3.

\subsubsection{Antiviral activity}

Many Bacillus subtilis lipopeptides have significant antiviral activity and are specific for this virus and bursitis virus (IBDV). They can effectively inhibit the infection and replication of NDV and IBDV, but do not affectPRV and PPV (Huang et al., 2006). Surfactin is the physical interface between membrane active surfaces (egSemly Forest virus, herpes simplex virus (HSV - 1a HSV - 2), vesicular stomatitis virus, immunodeficiency virus, monkey calicivirus and mouse encephalomyelitis virus). Due to chemical interactions, it is effective against certain viruses. And viral lipid membranes. Surfactant proteins, especially herpes viruses and retroviruses, inactivate enveloped viruses more effectively than enveloped viruses (Vollenbroich et al., 1997).

The number of carbon atoms in the fatty acid chain is another important factor that determines the ability of surfactants to mediate antiviral activity, and increased hydrophobicity of fatty acids can improve antiviral ability. During the inactivation process, surfactants are incorporated into the lipid bilayer, which leads to the complete destruction of the membrane containing viral proteins related to the adsorption and penetration of the virus (Kracht et al., 1999).

\subsubsection{Thrombolytic activity}

It also shows that surfactin has thrombolytic activity. At a concentration of 3 to $20 \mu \mathrm{M}$, the surfactant can improve the activation of prourokinase, promote the conformational change of plasminogen and improve fibrinolysis in vivo and in vitro (Kikuchi and Hasumi 2002). Kim's work shows that surfactants have antiplatelet activity not because of their surface interaction activity, but because of their effect on downstream signaling pathways (Kim et al., 2006).

It also shows that itulin has thrombolytic activity because it causes relatively little damage to the membrane of red blood cells, and then penetrates into itulin A according to the concentration of $\mathrm{K}^{+}$(Aranda et al., 2005).,

\subsubsection{Potential applications}

Some Bacilluslipopeptides are good substitutes for synthetic and antibacterial agents and can be used as safe and effective therapeutic agents. The unobserved side effect (NOAEL) level of oral surfactant $\mathrm{C}$ in rats was $500 \mathrm{mg} / \mathrm{kg}$ (Hwang et al., 2009; Sahnoun et al., 2014). This is especially important considering the increase in the number of resistant pathogens

\section{Volume 10 Issue 10, October 2021}


and the corresponding demand for more effective alternatives to antibacterial agents. As described above, Bacilluslipopeptide has many functions and can be used as an antibacterial compound and an effective therapeutic agent.

\subsubsection{Antibiotics}

Lipopeptide has great potential as an alternative to antibiotics. The abuse of antibiotics has led to the emergence of bacterial resistance, which has attracted more and more attention worldwide. There is an urgent need to identify and develop new drugs that replace conventional antibiotics. Bacillus lipolytica has broad - spectrum antibiotic properties and has excellent antibacterial activity against several multidrug - resistant bacteria (Das et al., 2008; Xuetal.2014; Zeriouh et al., 2011). In addition, due to the characteristics of biosurfactants, microorganisms may have difficulty developing resistance to these lips.

Some of the accused antibiotics produced the power of Streptococcus pneumoniae. Liquid lifting in agro surfactants, surfactants from Phytophthora, three things that are in the use of biological surfactants with surfactants produced by strains of the bacteria. These cyclic lipopeptide agents produced by the basil strain is also used as a biological control agent to reduce plant diseases.

\subsubsection{New - type feed additives}

Prolonged use of antibiotics in food additives can lead to the search for drug residues drug resistance, environmental and animal pollution. Bacillus lipopeptides will need to have excellent antibacterial properties and thermal stability, so that they can be developed as new food additives. A particularly important part of this process generally keeps a low max lipopeptide antibacterial activity of young people. In the intestine, the lipopeptide effectively controls the growth and reproduction balance of the intestinal flora without resistance to drugs and pathogenic microorganisms or side effects of the drug. These are all new materials should have an antibacterial green food additive.

\subsubsection{0. antitumor drug}

A large number of Bacillus lipopeptideas anti - tumor agents can be an obstacle to the development of cancer. Studies have shown that some of them multiple times by means of molecular recognition between the cells of the initiators of lascivious embraces, between, signaled totransduction, cell differentiation, cell - mediated immune response (Palanisamy and Raichur 2008) indicate that those likely to be lipopeptide developed as anti - tumor agents.

\subsubsection{1. drug delivery agent}

From Bacillusanritns, surfactants are the main component of microemulsion systems, where itself, along with the whole complex, to form a variety of about the uterus. Or dissolving only hydrophobic or hydrophilic drugs may be the presence of a basic divided period of the basic apparatus (almost spherical) differs from the continuous season. Biosurfactants is the best alternative to their other composition of synthetic nanoparticles and the recent trend to use them as a model for the construction of a green biosurfactants are more attractive alternatives to synthetic components. (Gudin et al., 2013).
Amino acid chain fatty acids and lengths of change, sharpe variants can improve their ability to provide high oral bioavailability from insulin to insulin. Actin variants have a more hydrophobic surface for amino acid residues. One can modify a rigid body with insulin $(\alpha-$ helix $)$ of flexible structure ( $\beta$ - random and the helix mesh), which provides for the epithelium eminent insulin eanalisintestii $f$. Therefore, there is great potential for the delivery of daily insulin monitoring of blood glucose (Zhang et al.2017).

\subsubsection{Other lorem applications}

In addition to the above, Bacillus subtilis loremccerulescenslipopeptide, there are other benefits as emergency thrombolytic lorem, anti - inflammatory drugs, antiviral drugs and Alzheimer's disease.

Surfactin shown potential for use in emergency thrombolytic lorem associated with pulmonary, myocardial and cerebral disorders. In these cases, superior to other available surfactants show the benefits of fewer effects of the thrombolytic agent.

It is not, it can be used for a long time can not be. Pulmonary embolism in co - surfactant rat models such as urokinase and mine management promotes lysis (Kikuchi and Hasumi 2003). Actin, preventing platelet aggregation can also improve the surface of fibrinolysis, inhibiting the formation of other blood - fibrin clots and promoting the diffusion of fibrinolytic agents (Lim et al., 2005).

Thus, preventing any living virus can possess several types of lipopeptide agents. The best anti - inflammatory effect is the best lipopeptide brand useful as anti - inflammatory agents. Byeon - induced activation of NF - kB study has shown that it was ordered by LPS can inhibit production and the first RAW264.7 macrophages, cells (Byeon et al., 2008). In addition, detergents may have shown beneficial effects in the treatment of Alzheimer's disease due to its ability to influence all of the amyloid protein $(\mathrm{A} ß(1-40))$ with fibrils ((Han et al., 2008).

\subsubsection{Synthesis of lipopeptides}

Bacillus thuringiensis with the lipopeptide synthesized using non - ferosomalsynthetase (NRPS), which has a very large number. heterogeneous systems to provide the sense of light in the words of these metabolic, and in what order of the nature of the product from the acids acid products of Bacillus lipopeptide which remained: in the peptides of the nature and nature of fatty acid, and the cyclization of branched chains, and the length of hickory. However, I tend to have a natural ability to produce mope lipopeptide. In addition to these various lipopeptide the constitution, the rule in a liquid, with low efficiency fermentation. This is a matter of lipopeptide separation and purification.

In addition, it has an effect that causes the formation of sharpe foam, which makes it difficult to control fermentation. This is why the lipopeptide of industrial production severely limited. Many attempts have been made to solve this problem, including the optimization of the dominant culture, the fermentation process improved and perfected by the production of the species (Coutts et al.2015 and brutLoper 2009, Jauregui al.2013).

Volume 10 Issue 10, October 2021 


\subsubsection{After extraction and purification of the} lipopeptide

Once in the culture broth chambers at $30^{\circ} \mathrm{M} 9100$, the bacterial cells are eliminated by centrifugation for 20 minutes through the lipopeptide (6) XG as well as sterile and filtration $(0.45 \mu \mathrm{m}) .3 \mathrm{~N} \mathrm{HCl}$ was added to precipitate a tripeptide Sharpe from the float will drop as a final $\mathrm{pH}$ of 2.0 to $4^{\circ} 100$ and 30 minutes. It was collected by centrifugation pouring acid (8) $\mathrm{g}$ for 1 hour at $4^{\circ} \mathrm{C}$ and dissolved in chloroform / methanol $(2,1, \mathrm{v} / \mathrm{v})$ from the security system. The solution is evaporated in vacuo.

The use of the solution dried in methanol and filtered through a $0.2 \mu \mathrm{m}$ hydrophilic non - pyrogenic membrane material (Sartorius AG, Göttingen, Germany). The filtrate was applied to 20.52 Sephadex column $(70 \mathrm{~cm} \mathrm{x} 16 \mathrm{~mm}$ internal diameter, Amersham Biosciences, Uppsala, Sweden) and size exclusion is to resolve to run it using elution of methanol. The cartoon was produced at $215 \mathrm{~nm}$ absorbance. A rotary evaporator and the expected role of the mixed antifungal activity experiment $\mathrm{C}$.

\subsubsection{Homo Analysis}

The protein was purified from lipopeptide of hydrolysed bonding by boiling in hydrochloric acid of $6 \%$ of phenol $n^{\circ}$ 1 at $22^{\circ}$ at 100110 hours. According to the Waters Pico Tag method (Cohen, S. A. and M. Meys T. L. Tarvin., 1989), amino acid analysis of the pre - column derivatization with phenyl isothiocyanate.

\subsubsection{Purification of tripeptidebiosurfactin}

And vice versa time to run the column LH - 20 Sepadex column in the field were used to purify the superior bio tripeptidesharpe of free time.

\section{Methods and Materials}

\subsection{Detection of Lipopeptides}

Lipopeptides are molecules containing a hydrophobic chain of fatty acids and a hydrophilic cyclic peptide that are expressed by bacteria, and some lipopeptides are used as antibiotics.

The bacillus is considered an effective microbial factory for the large - scale production of these types of biologically active molecules. There are three families of Bacillus lipopeptides: surfactin, iturin, and fengicin.

\subsection{Solvents}

All the chemicals and reagents used in this study were of analytical grade such as petroleum ether, ethanol (90\%) absoluteethanol, ethyl acetate and methanol, Chloroform. Distilled water, acetic unhydride, Sulphur acid, Nitric acid, Sodium hydroxide (20\% 10\%), HCL, alpha naphthol. Trioxyhydrindene Monohydrate, glycerol, Acetonitrile (Hplc grade): as reagent

\subsection{Equipment}

Magnetic stirring shaker, Water bath, Oven, Autoclave, Balance Incubator and Glass were test tubes, Petri dishes,
Beakers, Pipettes, Marker pen, Sensitive balance, Refrigerator, Funnel, Rotator evaporator, Stirrer, Filter Paper, droper, UV detector, Soxhlet extractor, Silica powder, TLC plat, Micropipette. Beaker. Fume chamber, Aluminium foil. Blower/ hand dryer, Spray gum, Glass column. Retort stand and clamp, Funnel. Round bottom flask, Glass jar/chamber, Cotton wool.

\subsection{Identification of surfactin using TLC}

Small volume of the sample as pipetted into a test tube and diluted with excess volume of methanol to reduce concentration and The TLC plate is then divided into three parts $-5,6$, and 7 then One drop of the sample is dropped onto each of the three parts of the TLC plates and dried and Three drops of methanol was dropped onto the sample to dilute and spread the sample adequately. Blow with hand dryer/blower to dry then $12 \mathrm{ml}$ of dichloromethane, $1 \mathrm{ml}$ of methanol and one drop of $\mathrm{HCl}$ was pipetted and mixed together into a beaker. The mixture was poured into the glass jar/chamber then The prepared TLC plate was made to stand in the glass jar/chamber with the reagent and covered then The set up was allowed to stand until the reagent completely immerses the TLC plate The TLC plate was then viewed under the UV light Clean and dry measuring beaker was obtained and some amount of silica powder was poured into it and the TLC plate was placed into it. Drops of $\mathrm{HCl}$ was added at the edges of the beaker to drop into the powder and It was gently put into the oven at 110 degree Celsius for $90 \mathrm{mins}$ then It was removed, dried and sprayed with trioxohydrindene monohydrate to make the red colour visible.

\subsection{Purification of surfactin using column chromatography}

The sample was prepared by mixing with some amount of silica powder. Care was taken to ensure that the sample thoroughly mixes with the sample and The glass column was clamped upright with the retort stand and With the aid of a funnel the glass column was filed with silica powder up to three third of its length, The prepared sample was then poured Into the silica powder in the column and cotton wool is then placed on it, then mixture of dichloromethane, methanol and $\mathrm{HCl}$ in the proportion 12: 1: 1 was then poured onto the cotton wool in excess amount into is opened to collect the various fractions. Five fractions of the sample was collected and Soxhlet extractor was used to dry the various fractions.

\subsection{Preparation of PDA medium}

\begin{tabular}{|l|}
\hline $200 \mathrm{~g}$ of boiling potato \\
\hline $20 \mathrm{~g}$ of glucose \\
\hline $16 \mathrm{~g}$ of agar \\
\hline $1000 \mathrm{ml}$ of water \\
\hline $20 \mathrm{~g}$ of glycerin \\
\hline One capsule of Amoxicillin \\
\hline
\end{tabular}




\subsection{Fungus cultivation}

Fungus cultivation done using soybean and PDA medium and water with different amount and the observation of spergillus niger was taked after $45 \mathrm{hr}$

\begin{tabular}{|c|c|c|}
\hline No & Soybean+Water + PDA medium+Asp. niger & Observation \\
\hline 1 & $25 \mathrm{~g}$ Soybean $+0 \mathrm{ml}$ water + PDA medium & $--_{-}^{-}-$ \\
\hline 2 & $25 \mathrm{~g}$ Soybean $+0 \mathrm{ml}$ water + PDA medium & $-\cdots$ \\
\hline 3 & $25 \mathrm{~g}$ Soybean $+3.125 \mathrm{ml}$ water + PDA medium & - . . - \\
\hline 4 & $25 \mathrm{~g}$ Soybean $+3.125 \mathrm{ml}$ water + PDA medium & $-\ldots$ \\
\hline $\mathbf{5}$ & $25 \mathrm{~g}$ Soybean $+6.25 \mathrm{ml}$ water + PDA medium & ----- \\
\hline 6 & $25 \mathrm{~g}$ Soybean $+6.25 \mathrm{ml}$ water + PDA medium & $-\ldots$ \\
\hline 7 & $25 \mathrm{~g}$ Soybean $+12.5 \mathrm{ml}$ water + PDA medium & +++ \\
\hline 8 & $25 \mathrm{~g}$ Soybean $+12.5 \mathrm{ml}$ water + PDA medium & ++++ \\
\hline 9 & $25 \mathrm{~g}$ Soybean $+25 \mathrm{ml}$ water + PDA medium & ++++++ \\
\hline 10 & $25 \mathrm{~g}$ Soybean $+25 \mathrm{ml}$ water + PDA medium & ++++++ \\
\hline 11 & $25 \mathrm{~g}$ Soybean $+50 \mathrm{ml}$ water +PDA medium & ++++++++ \\
\hline 12 & $25 \mathrm{~g}$ Soybean $+50 \mathrm{ml}$ water +PDA medium & +++++++++++ \\
\hline 13 & $25 \mathrm{~g}$ Soybean $+100 \mathrm{ml}$ water +PDA medium & Un successful \\
\hline 14 & $25 \mathrm{~g}$ Soybean $+100 \mathrm{ml}$ water + PDA medium & Un successful \\
\hline
\end{tabular}

\subsection{Bacteria Cultivation}

Bacteria cultivation was done using soybean and PDA medium and water with different amount with different
Bacteria: Bacillussubtillus and Bacillus subtillusnatto the observation between two bacteria was taked after $12 \mathrm{hr}$

\begin{tabular}{|c|c|c|}
\hline $\mathrm{No}$ & $\begin{array}{c}\text { Soybean }+ \text { Water }+ \text { PDA medium }+ \text { Bacillus. sub } \\
\text { natto }\end{array}$ & Observation \\
\hline 1 & $20 \mathrm{~g}$ Soybean $+0 \mathrm{ml}$ water + PDA medium + B. sub & --- \\
\hline 2 & $20 \mathrm{~g}$ Soybean $+0 \mathrm{ml}$ water + PDA medium + B. sub & --- \\
\hline 3 & $\begin{array}{c}20 \mathrm{~g} \text { Soybean }+2.5 \mathrm{ml} \text { water }+ \text { PDA medium }+\mathrm{B} . \\
\text { sub }\end{array}$ & \\
\hline 4 & $\begin{array}{c}20 \mathrm{~g} \text { Soybean }+2.5 \mathrm{ml} \text { water }+ \text { PDA medium }+\mathrm{B} \text {. } \\
\text { sub }\end{array}$ & --- \\
\hline 5 & 20 g Soybean $+5 \mathrm{ml}$ water + PDA medium + B. sub & --- \\
\hline 6 & $20 \mathrm{~g}$ Soybean $+5 \mathrm{ml}$ water + PDA medium + B. $\mathrm{sub}$ & --- \\
\hline 7 & $20 \mathrm{~g}$ Soybean $+10 \mathrm{ml}$ water + PDA medium + Natto & ++ \\
\hline 8 & $20 \mathrm{~g}$ Soybean $+10 \mathrm{ml}$ water + PDA medium + Natto & +++ \\
\hline 9 & $20 \mathrm{~g}$ Soybean $+20 \mathrm{ml}$ water + PDA medium + Natto & ++++ \\
\hline 10 & $20 \mathrm{~g}$ Soybean $+20 \mathrm{ml}$ water + PDA medium + Natto & ++++ \\
\hline 11 & $20 \mathrm{~g}$ Soybean $+40 \mathrm{ml}$ water + PDA medium + Natto & ++++++ \\
\hline 12 & $20 \mathrm{~g}$ Soybean $+40 \mathrm{ml}$ water + PDA medium + Natto & ++++++ \\
\hline
\end{tabular}

\subsection{Co - culture of Bacteria against Fungus}

Co - culturing of bacteriaagainst fungus done using two different bacteria (Bacillus subtilis, Bacillussubtillisnatto) and two different fungus (Aspergillusniger. D. fungus) to know which bacteria and fungus graw fast

\begin{tabular}{|c|c|c|c|c|c|}
\hline NO & Soybean+Water+A. niger Fungus & & NO & Soybean+Water+D. Fungus & \\
\hline 1 & $100 \mathrm{~g}+13.75 \mathrm{ml}+\mathrm{A}$. niger & $-\ldots$ & 8 & $100 \mathrm{~g}+13.75 \mathrm{~m}+\mathrm{D}$. fungus & $-\cdots$ \\
\hline 2 & $100 \mathrm{~g}+17.5 \mathrm{ml}+\mathrm{A} \cdot$ niger & $\ldots$ & 9 & $100 \mathrm{~g}+17.5 \mathrm{ml}+\mathrm{D}$. fungus & $-\cdots$ \\
\hline 3 & $100 \mathrm{~g}+21.25 \mathrm{ml}+\mathrm{A}$. niger & $\ldots$ & 10 & $100 \mathrm{~g}+21.25 \mathrm{ml}+\mathrm{D}$. fungus & $-\ldots$ \\
\hline 4 & $100 \mathrm{~g}+21.25 \mathrm{ml}+$ A. niger & $\ldots$ & 11 & $100 \mathrm{~g}+21.25 \mathrm{ml}+\mathrm{D}$. fungus & $-\cdots$ \\
\hline 5 & $100 \mathrm{~g}+21.25 \mathrm{ml}+$ A. niger & $\cdots$ & 12 & $100 \mathrm{~g}+21.25 \mathrm{ml}+\mathrm{D}$. fungus & $\cdots$ \\
\hline 6 & $100 \mathrm{~g}+32.5 \mathrm{ml}+$ A. niger & $\ldots$ & 13 & $100 \mathrm{~g}+32.5 \mathrm{ml}+\mathrm{D}$. fungus & $\ldots$ \\
\hline 7 & $100 \mathrm{~g}+36.25 \mathrm{ml}+\mathrm{A}$. niger & $\ldots$ & 14 & $100 \mathrm{~g}+36.25 \mathrm{ml}+\mathrm{D}$. fungus & - \\
\hline
\end{tabular}

\begin{tabular}{|l|l|c|c|l|c|}
\hline & Soybean+Water+B. subtillus & & & Soybean+Water+Natto & \\
\hline $\mathbf{1 5}$ & $25 \mathrm{~g}+31.25 \mathrm{ml}+$ B. subtillis & $\mathbf{+ +}$ & $\mathbf{2 2}$ & $25 \mathrm{~g}+31.25 \mathrm{ml}+$ Natto & ++++ \\
\hline $\mathbf{1 6}$ & $25 \mathrm{~g}+37.5 \mathrm{ml}+$ B. subtillis & ++ & $\mathbf{2 3}$ & $25 \mathrm{~g}+37.5 \mathrm{ml}+$ Natto & ++++ \\
\hline $\mathbf{1 7}$ & $25 \mathrm{~g}+43.75 \mathrm{ml}+$ B. subtillis & $\mathbf{+ +}$ & $\mathbf{2 4}$ & $25 \mathrm{~g}+43.75 \mathrm{ml}+$ Natto & ++++ \\
\hline $\mathbf{1 8}$ & $25 \mathrm{~g}+50 \mathrm{ml}+$ B. subtillis & $\mathbf{+ +}$ & $\mathbf{2 5}$ & $25 \mathrm{~g}+50 \mathrm{ml}+$ Natto & ++++ \\
\hline $\mathbf{1 9}$ & $25 \mathrm{~g}+56.25 \mathrm{ml}+$ B. subtillis & $\mathbf{+ +}$ & $\mathbf{2 6}$ & $25 \mathrm{~g}+56.25 \mathrm{ml}+$ Natto & ++++ \\
\hline $\mathbf{2 0}$ & $25 \mathrm{~g}+62.5 \mathrm{ml}+$ B. subtillis & $\mathbf{+ +}$ & $\mathbf{2 7}$ & $25 \mathrm{~g}+62.5 \mathrm{ml}+$ Natto & ++++ \\
\hline $\mathbf{2 1}$ & $25 \mathrm{~g}+68.75 \mathrm{ml}+$ B. subtillis & $\mathbf{+ +}$ & $\mathbf{2 8}$ & $25 \mathrm{~g}+68.75 \mathrm{ml}+$ Natto & ++++ \\
\hline
\end{tabular}

\section{Result \& Discussion}

\subsection{Detection of Lipopeptides}

Lipopeptides is a molecule that contain hydrophobic fatty acid chains and hydrophilic cyclic peptides, Bacteria express these molecules and certain lipopeptides are used as antibiotics.

Bacillus genuses are considered as efficient microbial factories for the large - scale production as manufacturing of such type of bioactive molecules. Bacillus lipopeptides has three families which are: Surfactin, Iturin, and Fengycin.

\subsection{Solvents}

All the chemicals and reagents used in this study were of analytical grade such as petroleum ether, ethanol (90\%) absoluteethanol, ethyl acetate and methanol, Chloroform. Distilled water, acetic unhydride, Sulphuric acid, Nitricacid, Sodium hydroxide (20\% 10\%), HCL, alpha naphthol. Trioxyhydrindene Monohydrate, glycerol, silica gel, sephadex LH 20Acetonitrle (Hplc grade) Trioxyhydrindene Monohydrate: as reagent 


\section{International Journal of Science and Research (IJSR)}

ISSN: 2319-7064

SJIF (2020): 7.803

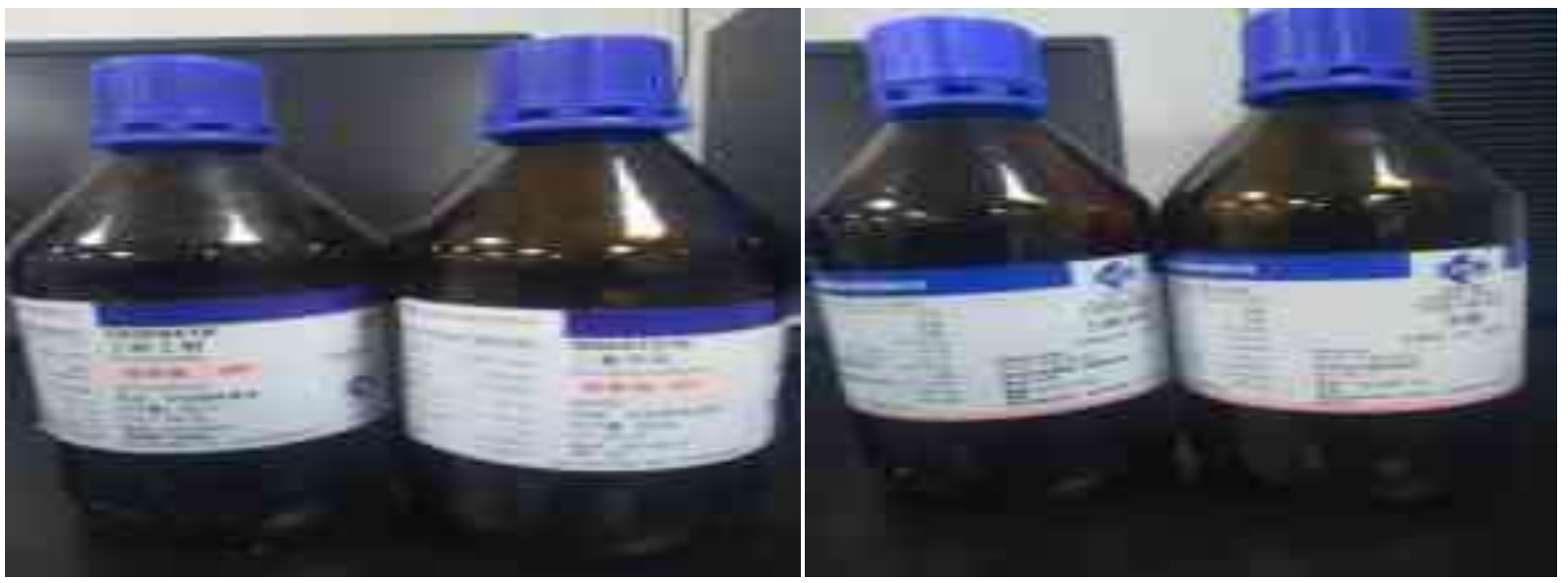

Figure 3: Chemical solvent
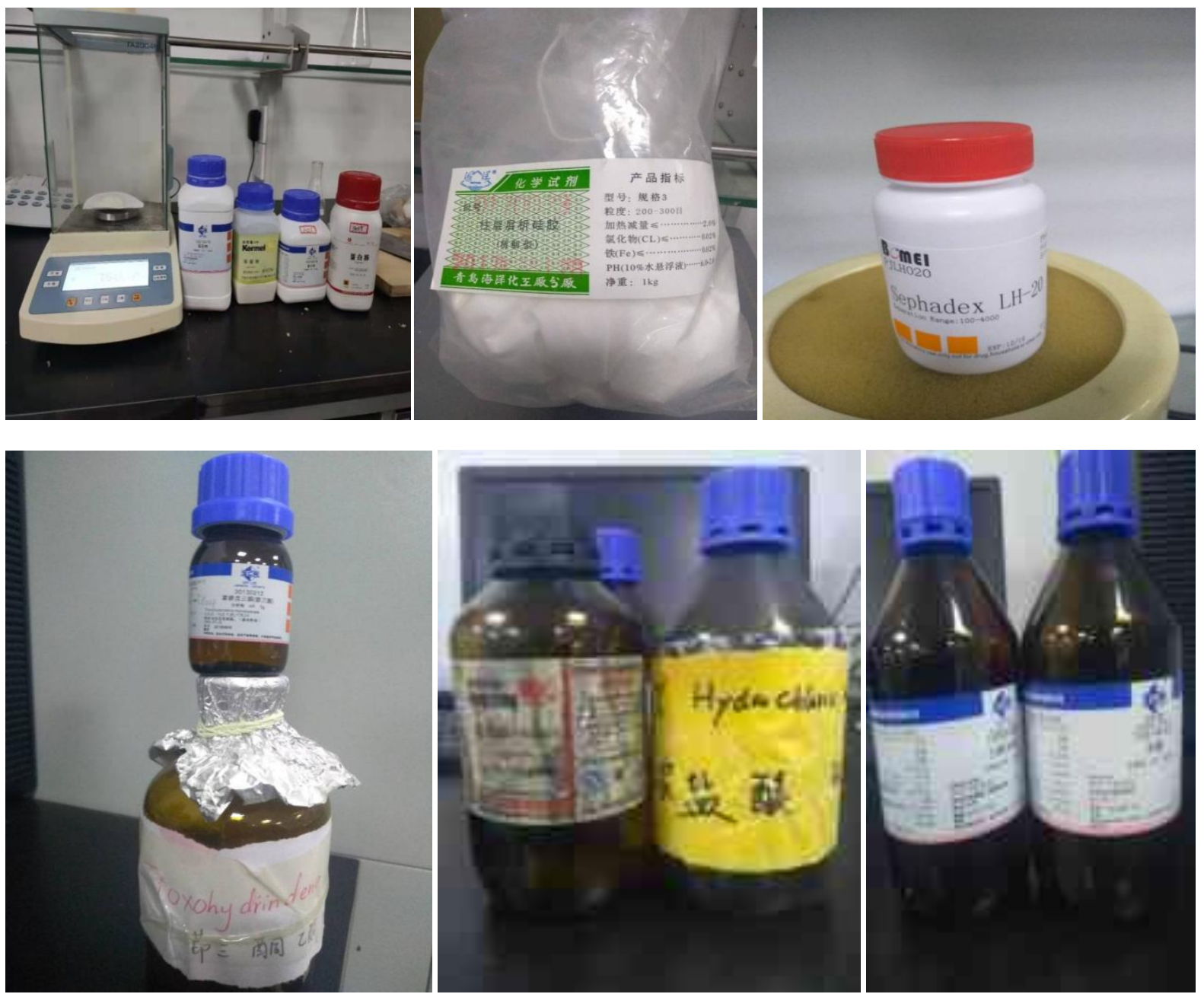

Figure 4: Chemical solvent

\subsection{Equipment}

Magnetic stirring shaker, Water bath, Oven, Autoclave, Balance Incubator and Glass were test tubes, Petri dishes, Beakers, Pipettes, Marker pen, Sensitive balance, Refrigerator, Funnel, Rotator evaporator, Stirrer, Filter
Paper, droper, UV detector, Soxhlet extractor, Silica powder, TLC plat, Micropipette. Beaker. Fume chamber, Aluminium foil. Blower/hand dryer, Spray gum, Glass column. Retort stand and clamp, Funnel. Round bottom flask, Glass jar/chamber, Cotton wool.

Volume 10 Issue 10, October 2021 www.ijsr.net 


\section{International Journal of Science and Research (IJSR)}

ISSN: 2319-7064

SJIF (2020): 7.803

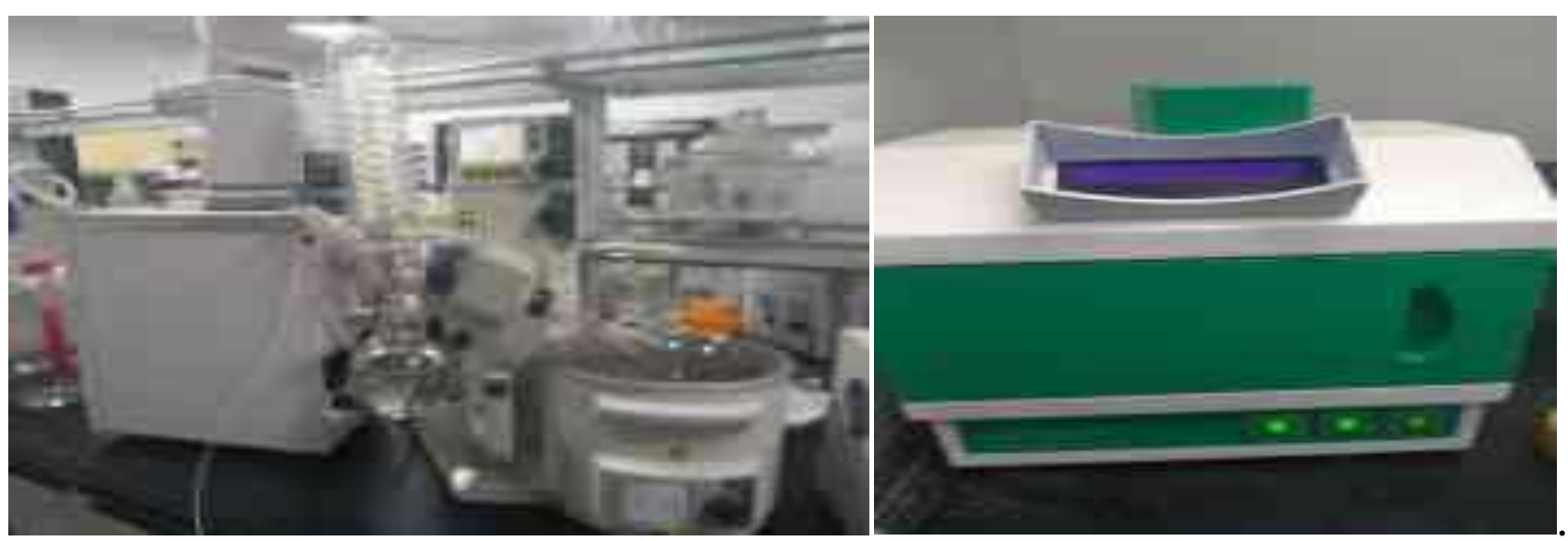

Figure 5: Soxhlet

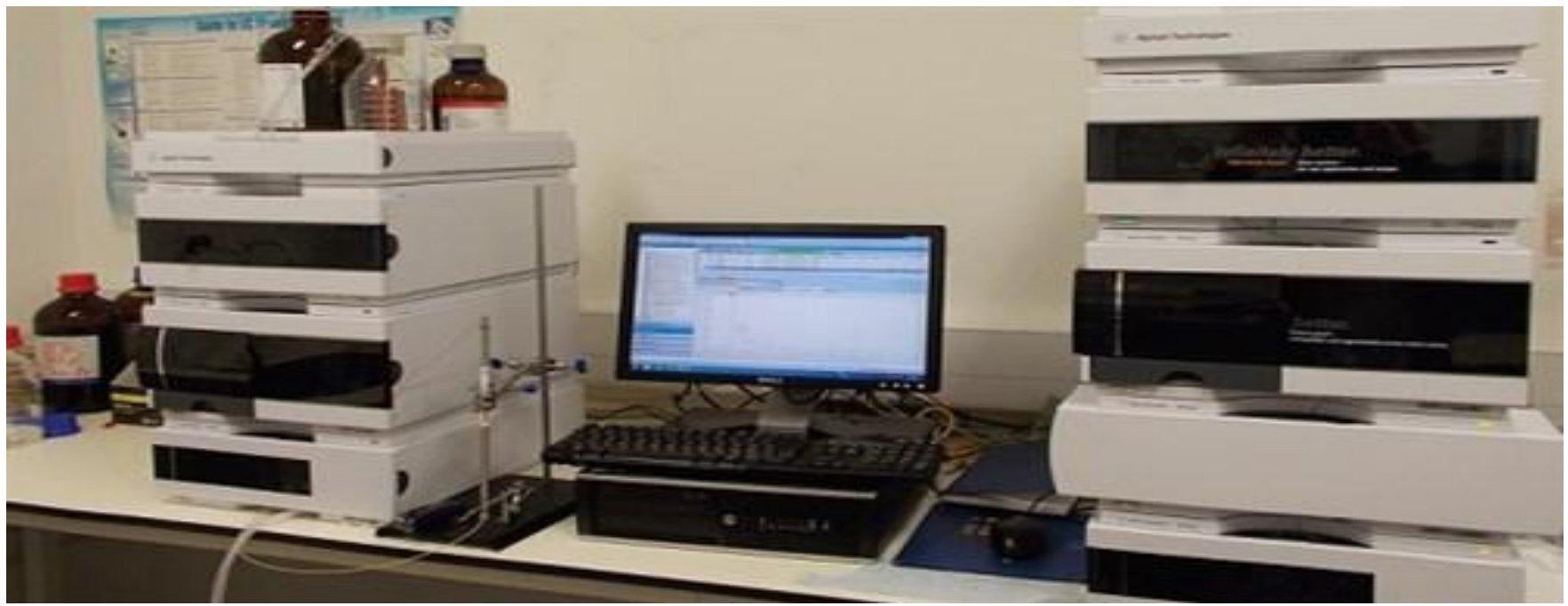

Figure 6: HPLC chromatography

\subsection{Identification of surfactin using TLC}

When the TLC was observed under UV light, no distinct colour change was noticed between the different components of the sample. But when it was viewed after the reaction with $\mathrm{HCl}$ and silica powder at 110 degree Celsius at 90mins oven, a distinct red color was observed indicating the presence of cyclo - pepetide.
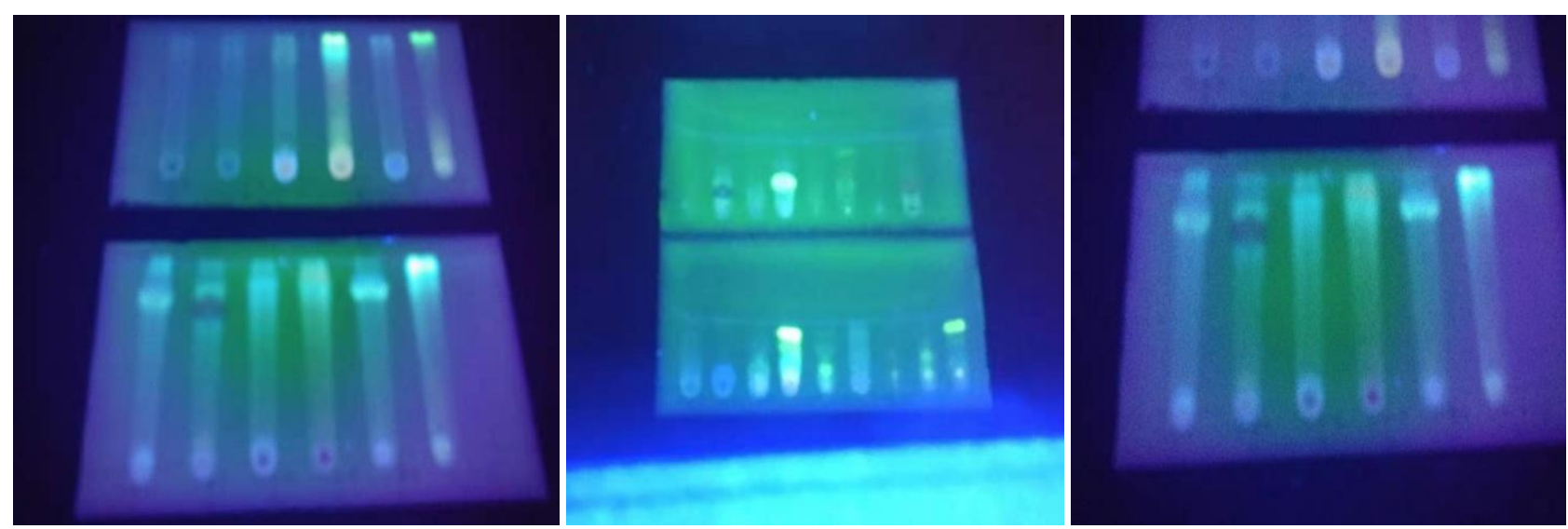

Volume 10 Issue 10, October 2021 www.ijsr.net 


\section{International Journal of Science and Research (IJSR)}

ISSN: 2319-7064

SJIF (2020): 7.803

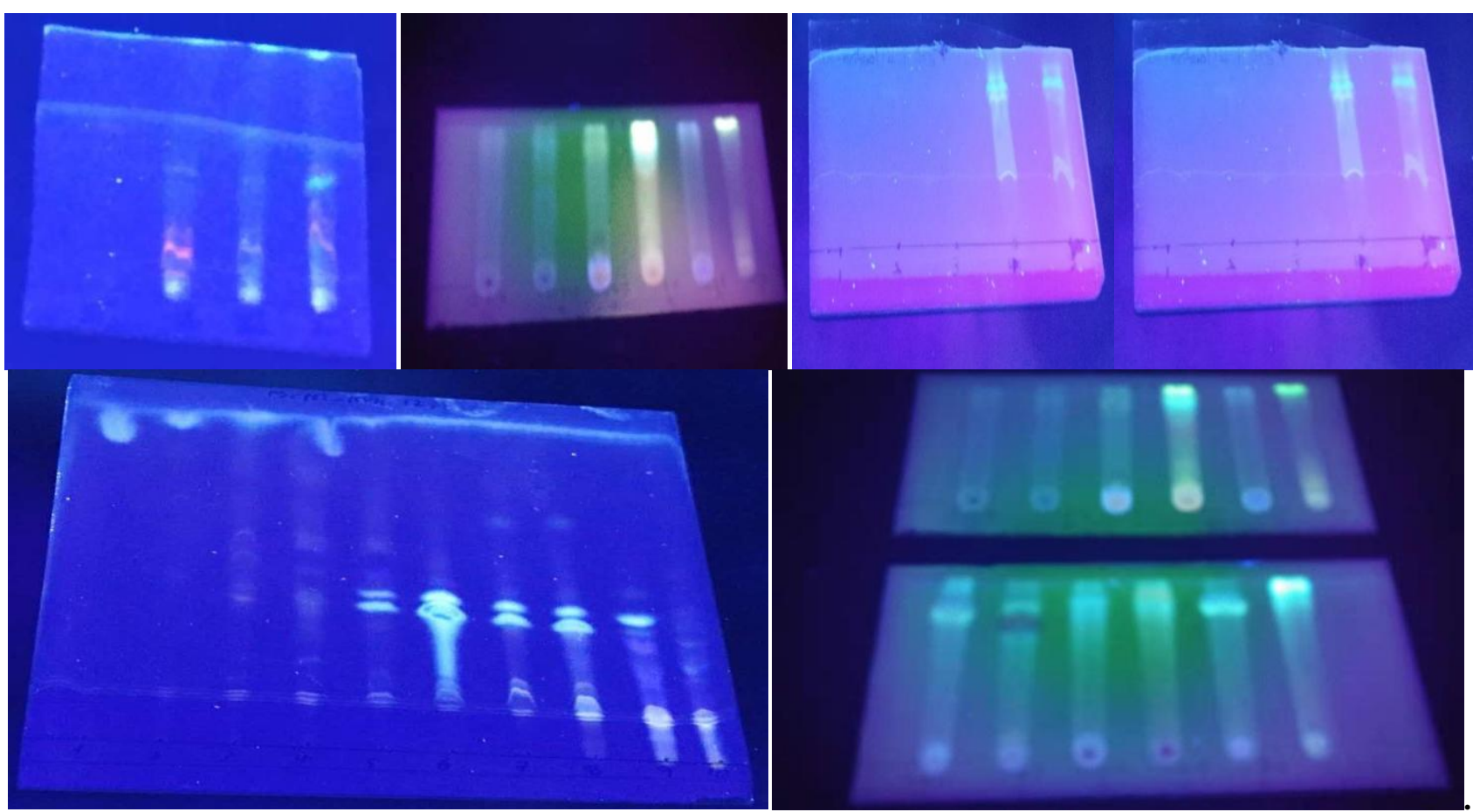

Figure 7: TLC chromatogtaphy for surfactin

TLC after reaction

After collecting five fractions of the sample from the column. Fraction number 4 and 5 were detected to be of a pure compound. While 1, 2 and 3 were found to be of no pre compounds
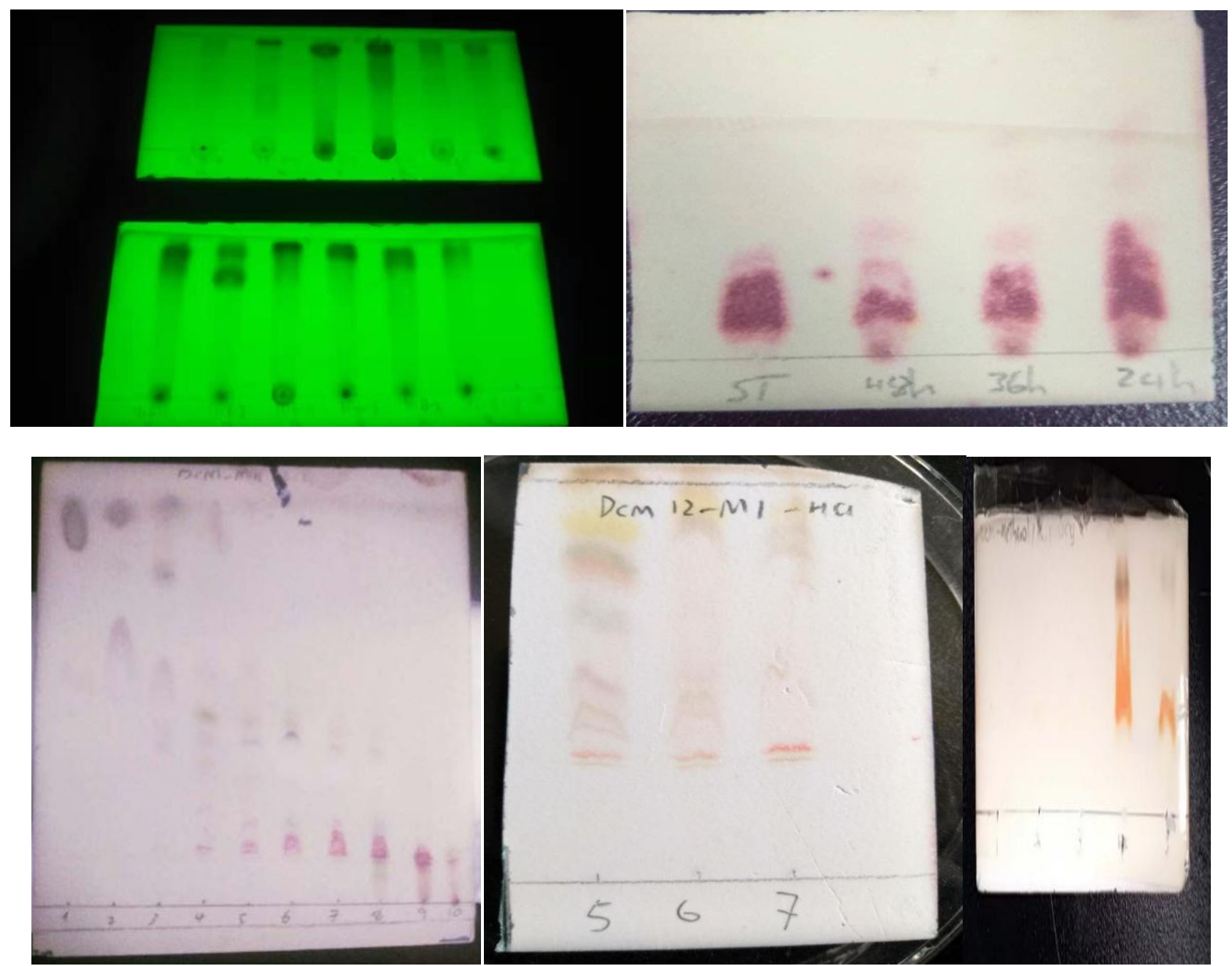

Figure 8: TLC chromatography for surfactin after reaction

Volume 10 Issue 10, October 2021 www.ijsr.net

Licensed Under Creative Commons Attribution CC BY 


\section{International Journal of Science and Research (IJSR) \\ ISSN: 2319-7064 \\ SJIF (2020): 7.803}

4.5. Purification of surfactin using column \& HPLC chromatography

The sample was preparedby mixing with some amount of silica powder. Care was taken to ensure that the sample thoroughly mixes with the sample and The glass column was clamped upright with the retort stand and With the aid of a funnel the glass column was filed with silica powder up to three third of its length, The prepared sample was then poured Into the silica powder in the column and cotton wool is then placed on it, then mixture of dichloromethane, methanol and $\mathrm{HCl}$ in the proportion 12: 1: 1 was then poured onto the cotton wool in excess amount into is opened to collect the various fractions. Five fractions of the sample was collected and Sexhelt extractor was used to dry fractions.

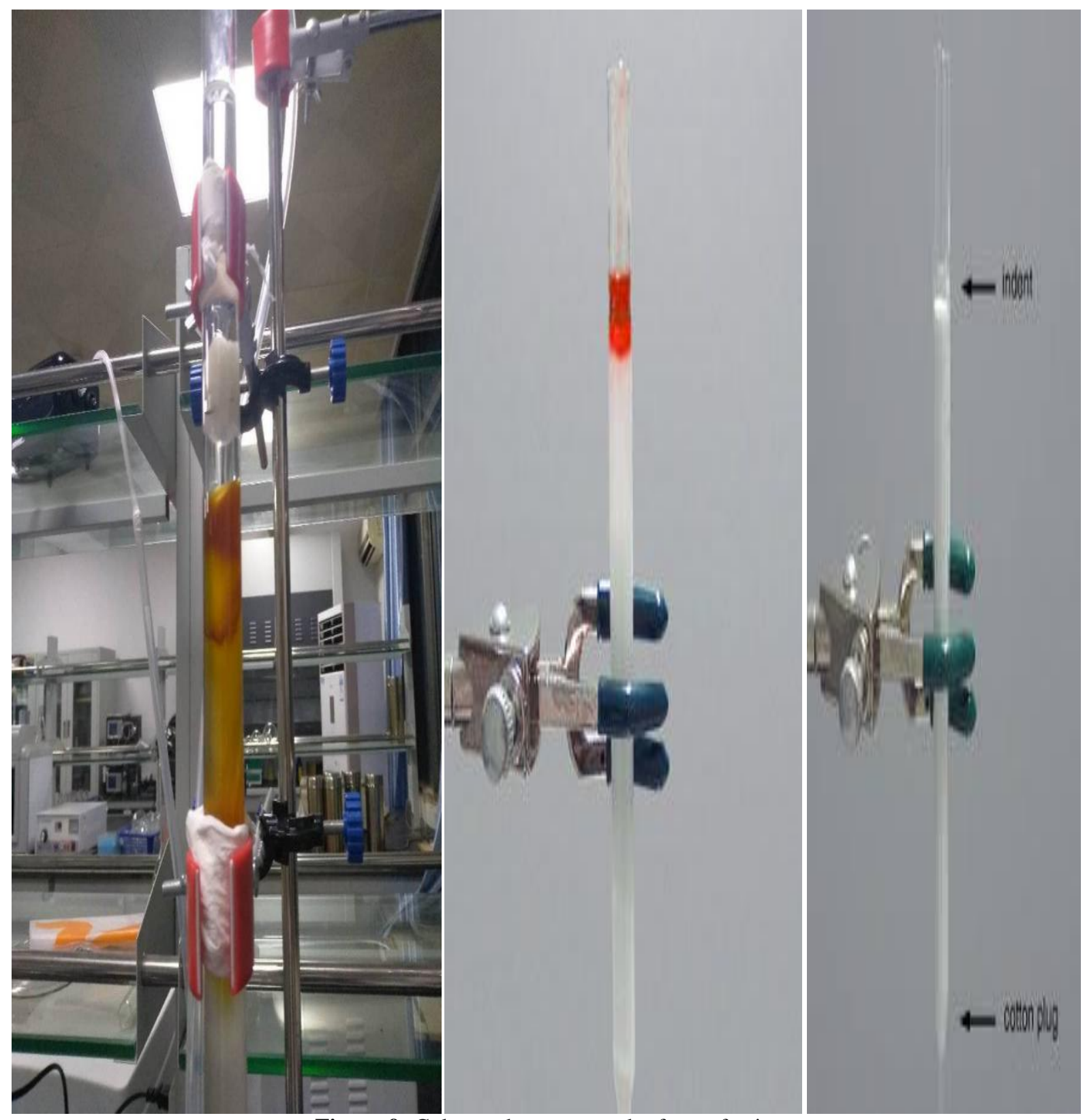

Figure 9: Column chromatography for surfactin

Volume 10 Issue 10, October 2021 www.ijsr.net 

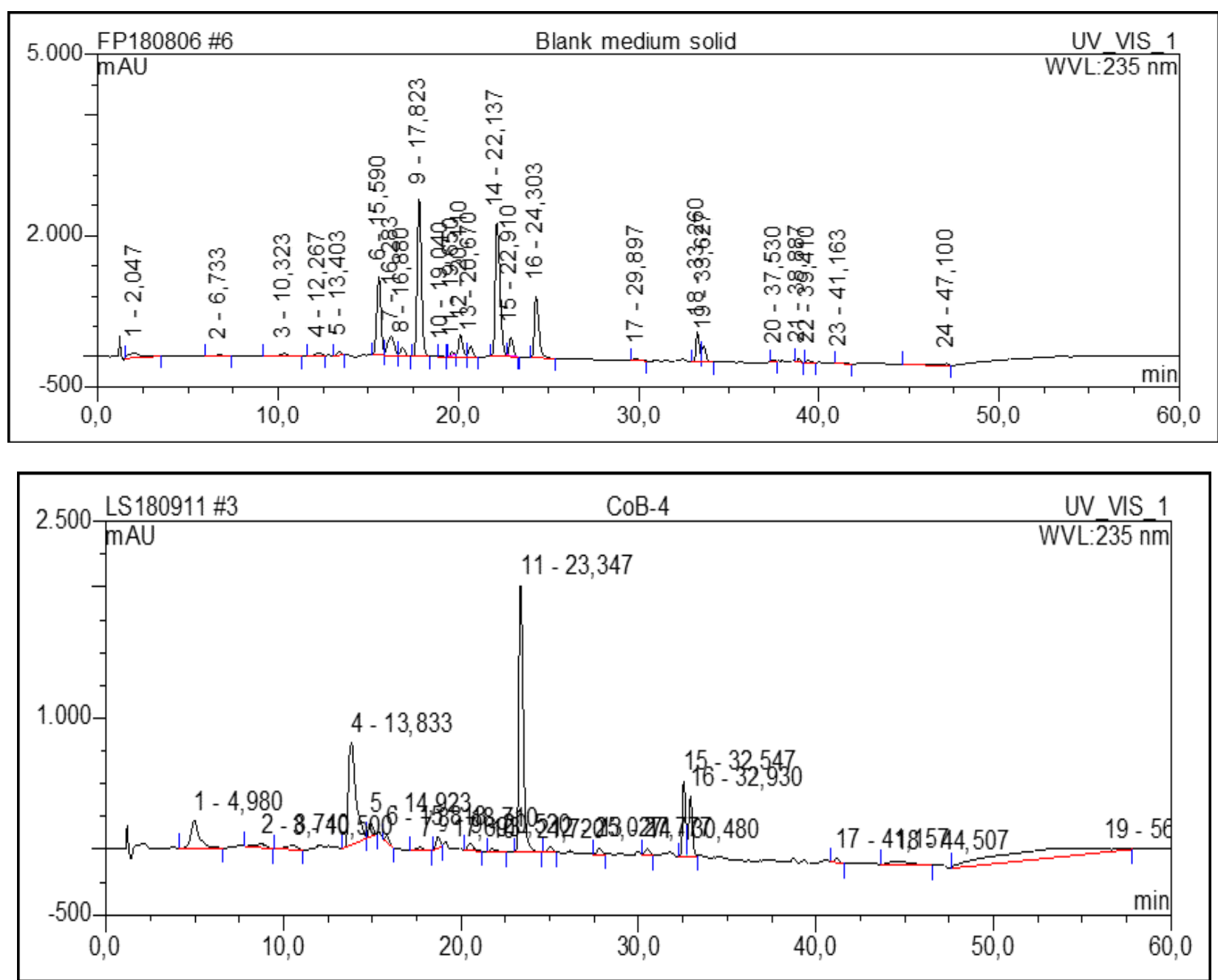

Figure 10: HPLC chromatography for surfactin

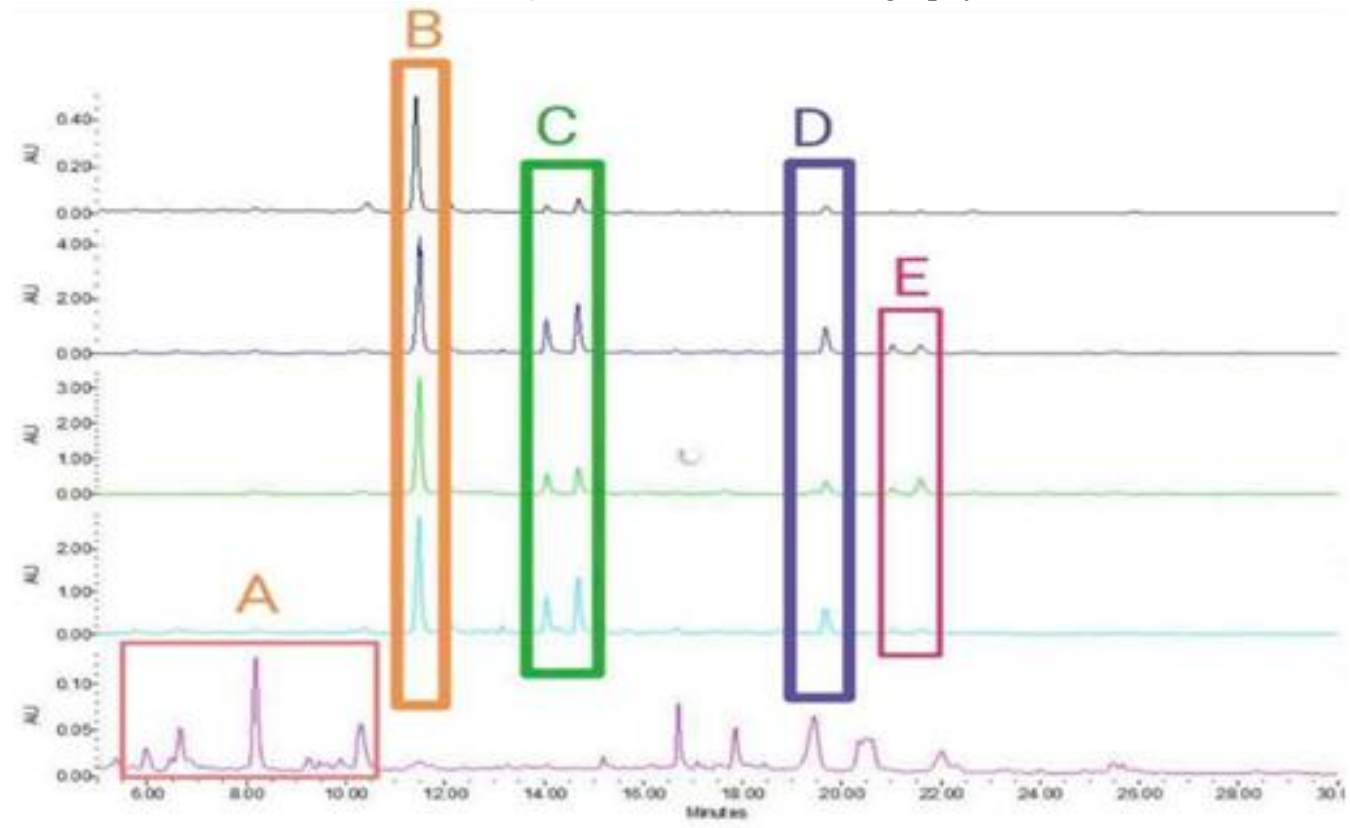

Fungal control

Co-cultivation 3

Co-cultivation 3

Co-cultivation 3

Fig10.1: HPLC chromatography for surfactin

\section{Bacteria control}

Volume 10 Issue 10, October 2021 www.ijsr.net

Licensed Under Creative Commons Attribution CC BY 


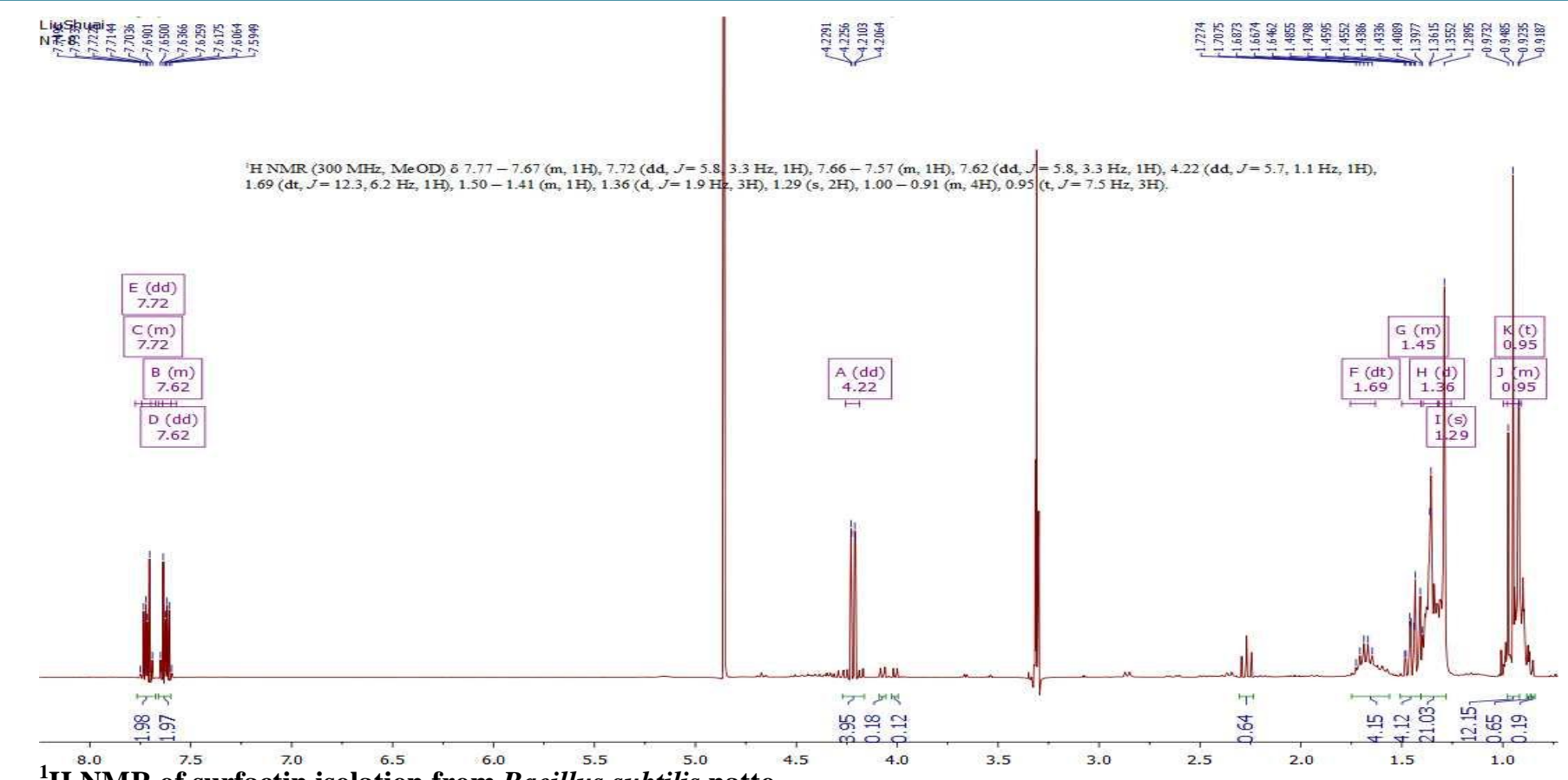

${ }^{\mathbf{1}} \mathbf{H}$ NMR of surfactin isolation from Bacillus subtilis natto

Figure 10.2: NMR

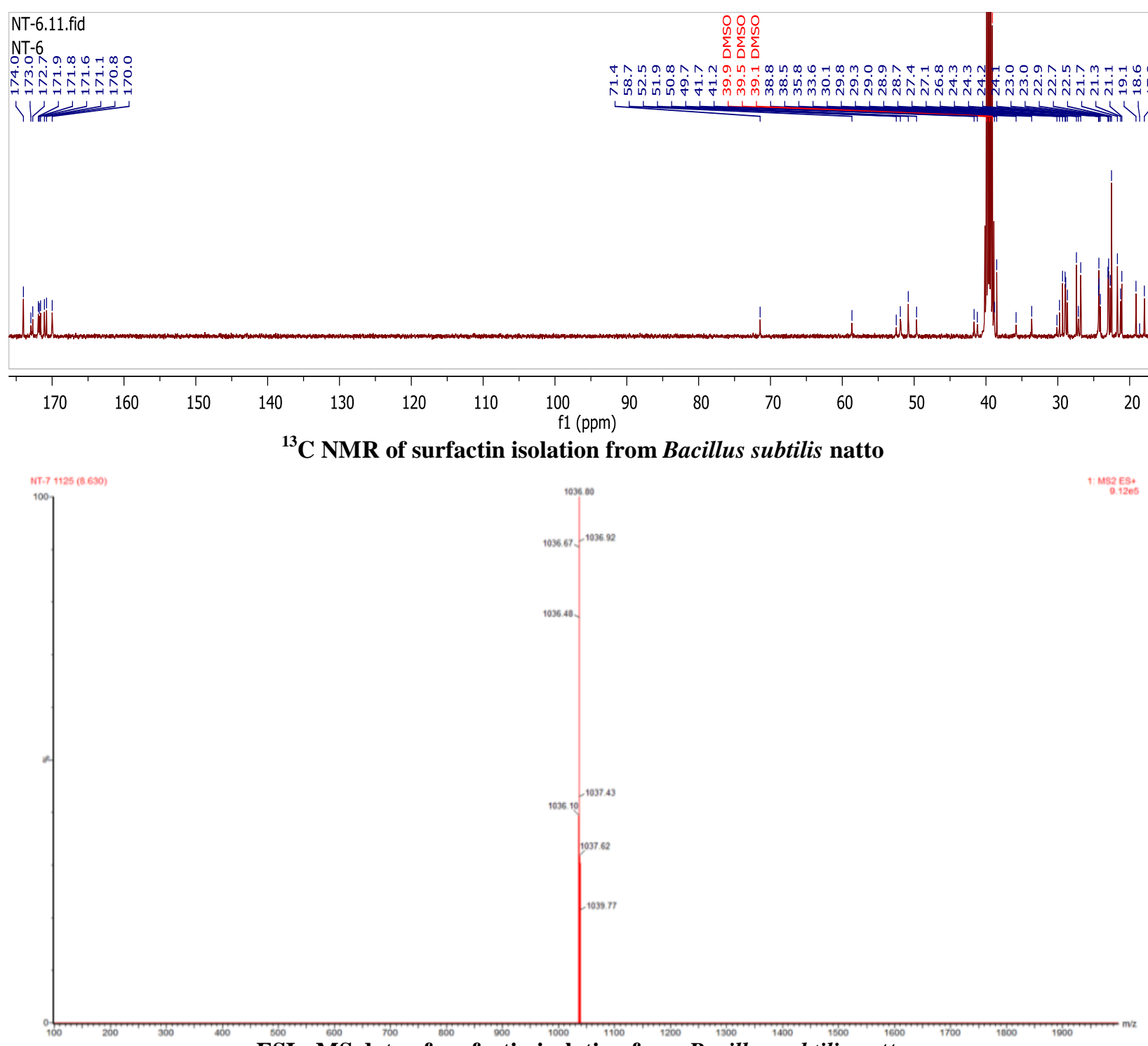

ESI - MS data of surfactin isolation from Bacillus subtilis natto

Volume 10 Issue 10, October 2021

www.ijsr.net

Licensed Under Creative Commons Attribution CC BY 


\section{International Journal of Science and Research (IJSR) \\ ISSN: 2319-7064 \\ SJIF (2020): 7.803}

\section{Fungus cultivation}

Observation was made after 45 hours of incubatingbetweenD. fungus\&Spergillusniger.

\begin{tabular}{|l|l|}
\hline D. fungus & Spergillusniger \\
\hline $1 \& 2-$ there was no growth & $12 \& 11-$ much growth of fungus than the rest of the bottles \\
$3 \& 4-$ there was no growth & $10 \& 9-$ there was growth observed but not a much as in $12 \& 11$ \\
$5 \& 6-$ there was no growth & $8 \& 7-$ there was little growth \\
\hline
\end{tabular}
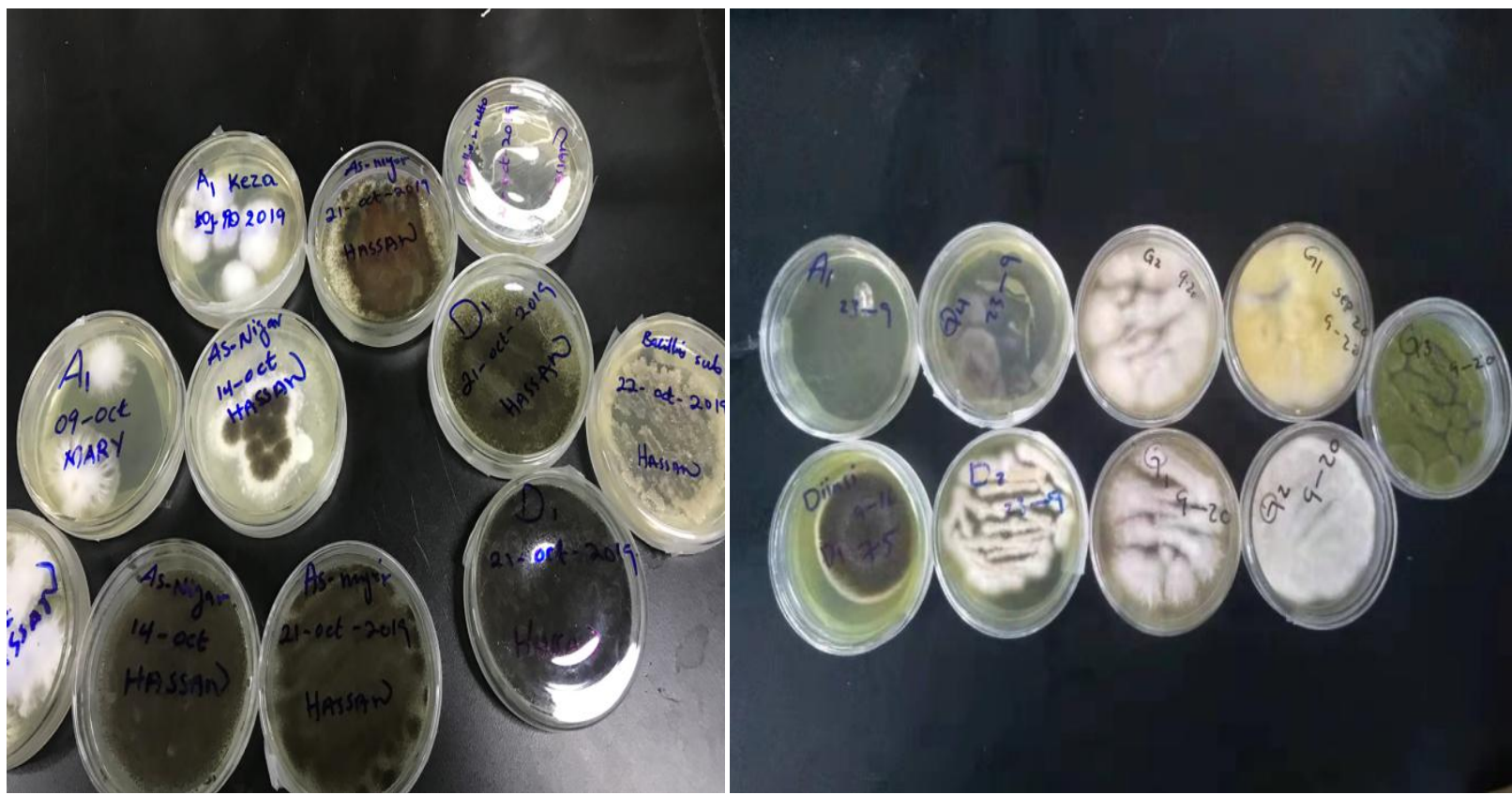

Figure 11: Fungus cultivation
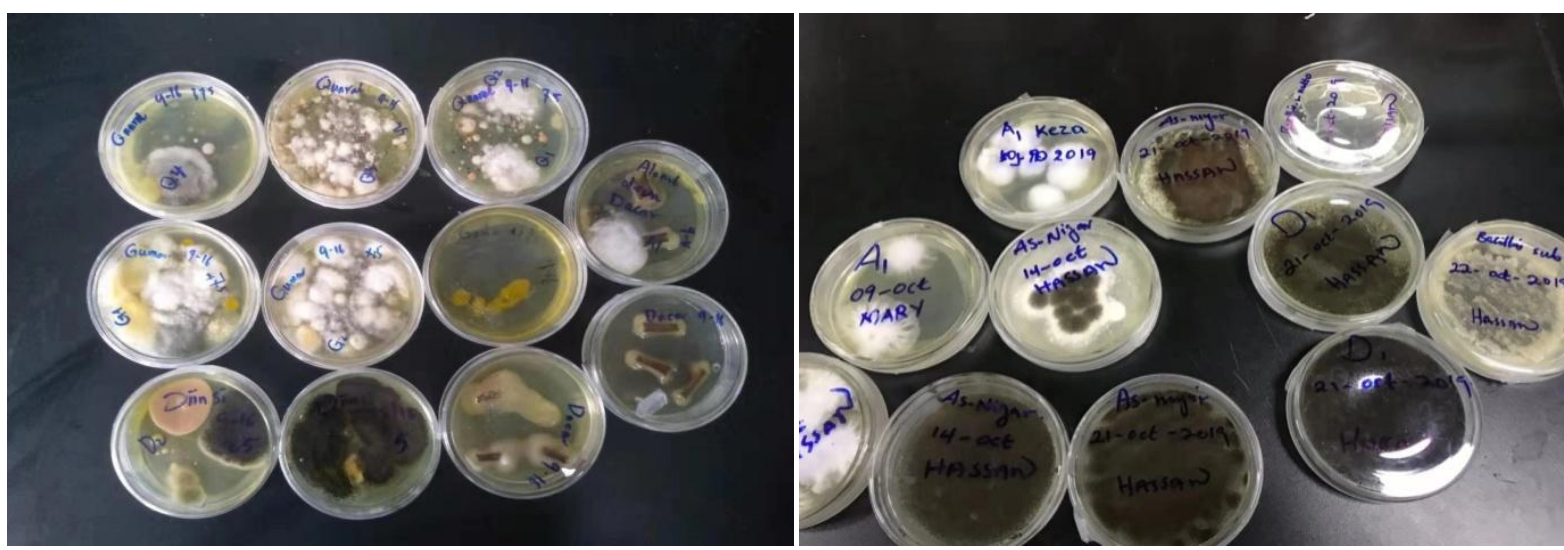

Figure 11.1: Fungus cultivation
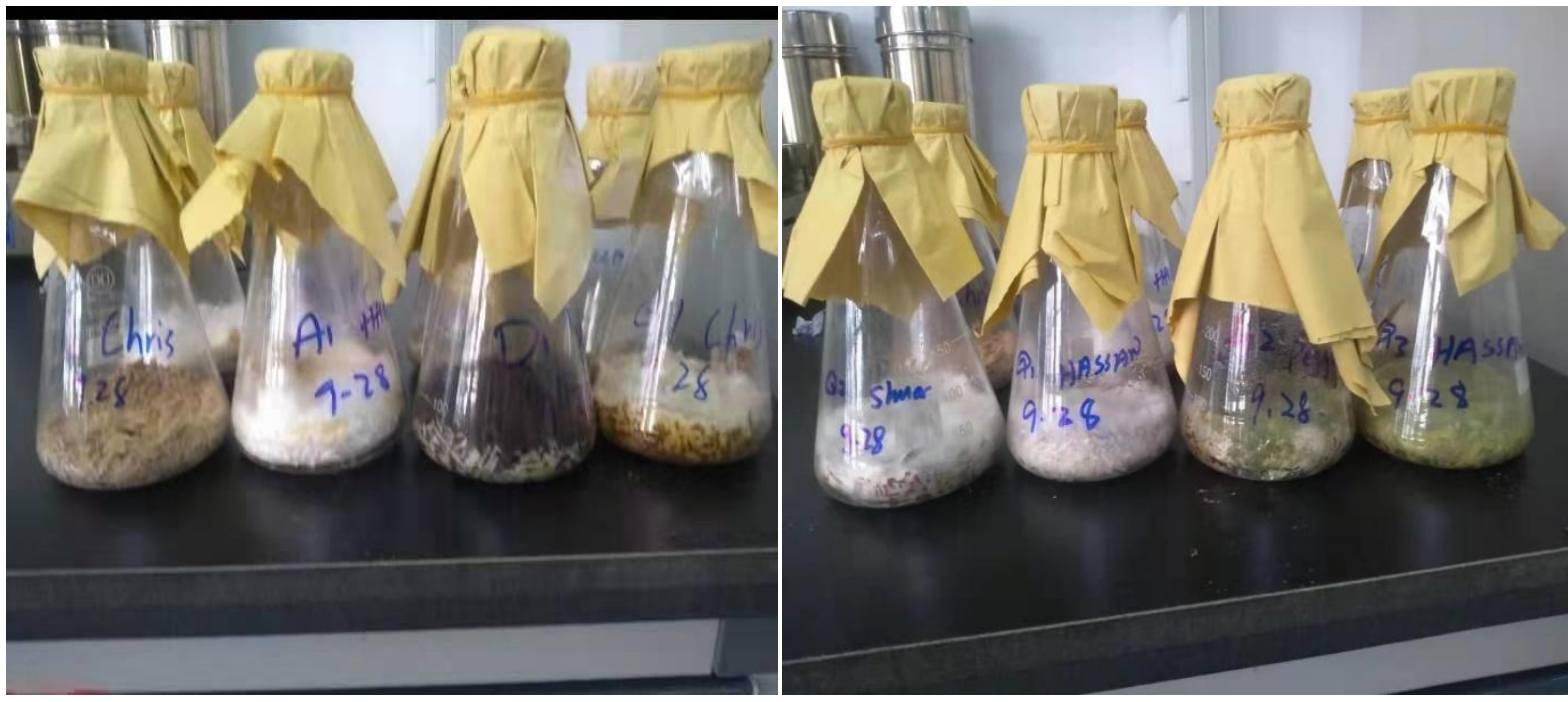

Figure 11.2: Fungus cultivation

Volume 10 Issue 10, October 2021

www.ijsr.net

Licensed Under Creative Commons Attribution CC BY 


\section{International Journal of Science and Research (IJSR)}

ISSN: 2319-7064

SJIF (2020): 7.803

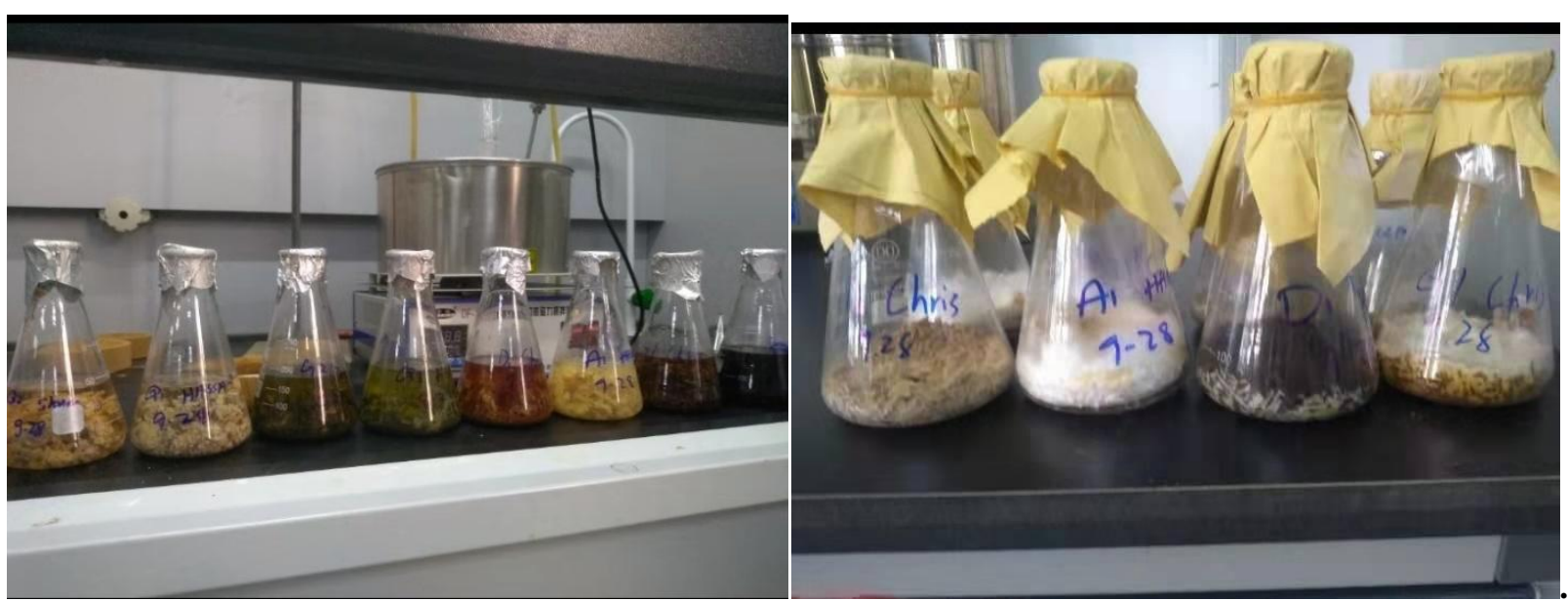

Figure 11.3: Fungus cultivation

\section{Bacteria cultivation}

Observation was conducted after 4 days between Bacillus subtilis and Bacillus subtilisnatto

\begin{tabular}{|l|l|}
\hline Bacillus subtilis & $\begin{array}{l}\text { Bacillussubtilisnatto } \\
\text { observation }\end{array}$ \\
\hline Bacillus subtilis & Bacillus natto \\
$11-$ intense bacterial growth was observed & $12-$ much growth was observed than in Bacillus subtilis \\
$9 \& 7-$ little growth was observed & $8-$ slight growth \\
$5,3 \& 1-$ no growth was observed & $6,4 \& 2-$ there was no growth observed \\
\hline
\end{tabular}

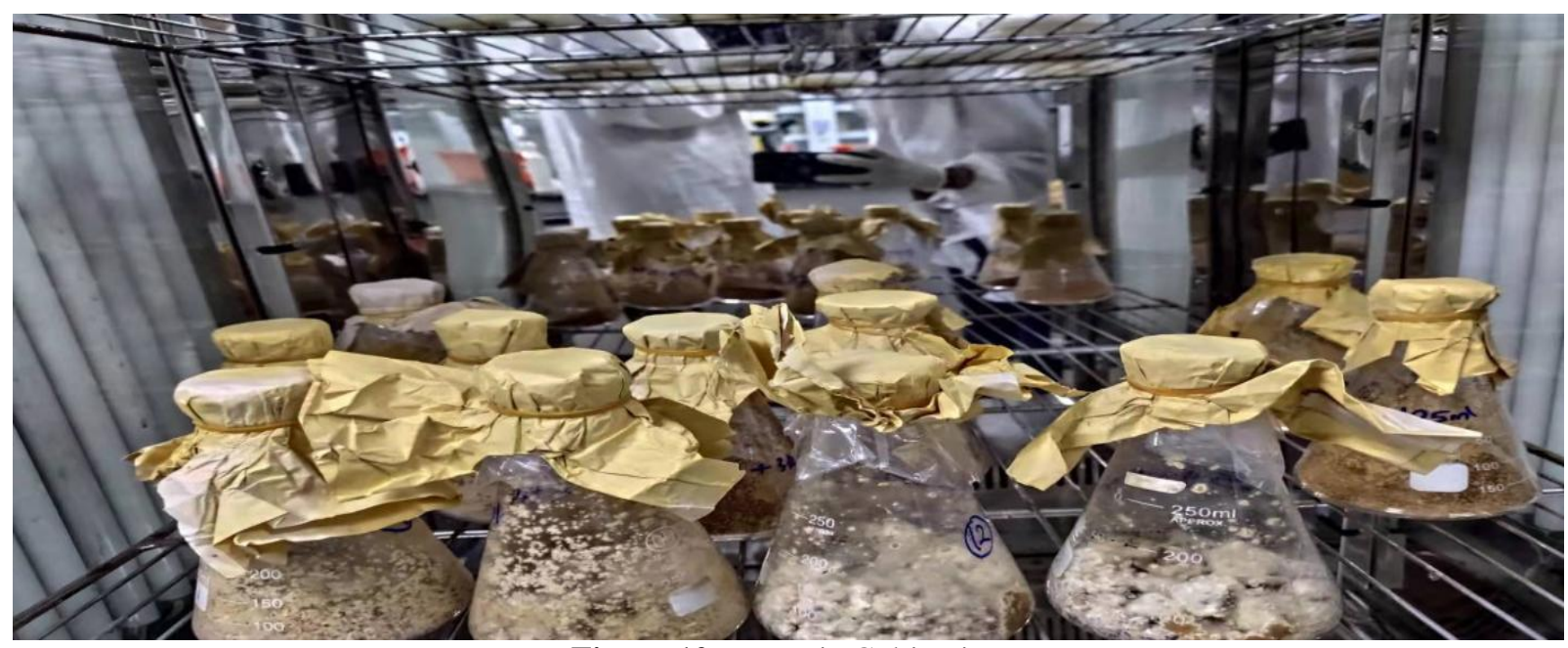

Figure 12: Bacteria Cultivation
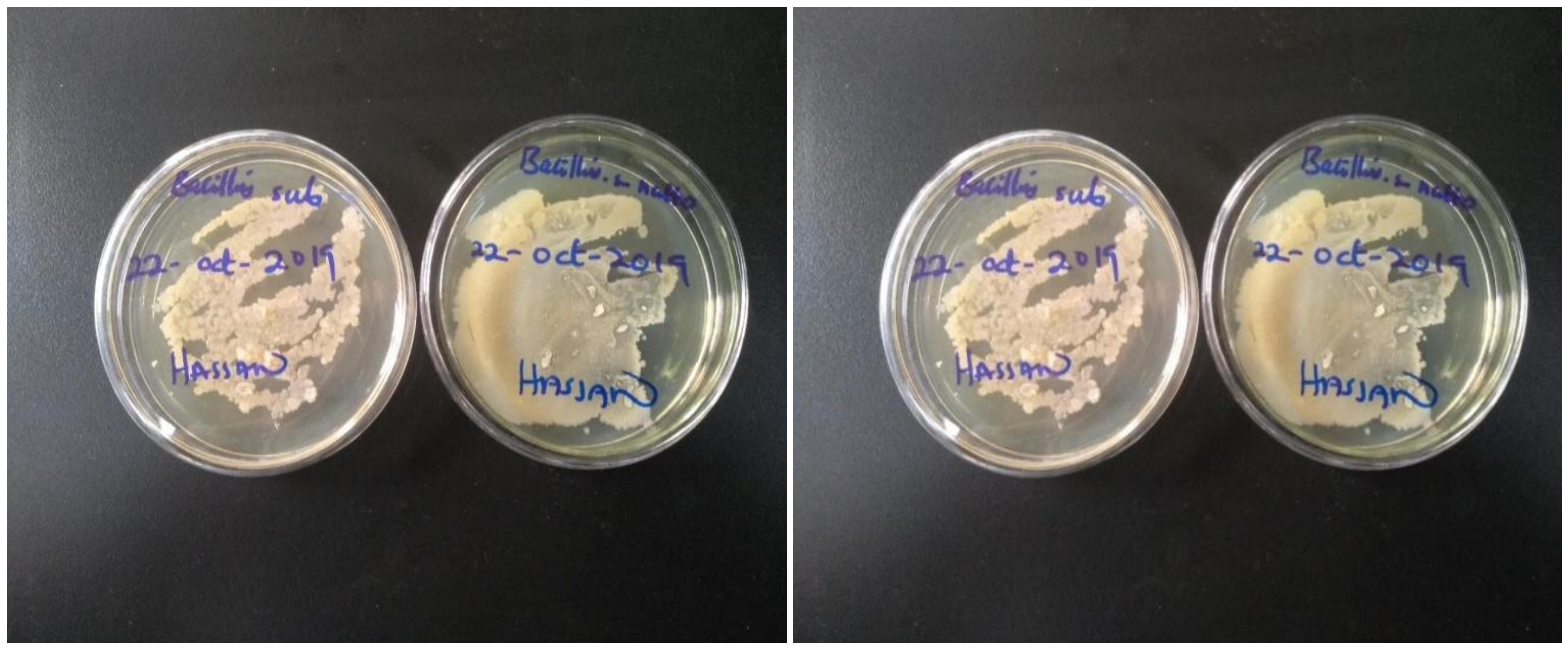

Volume 10 Issue 10, October 2021

www.ijsr.net

Licensed Under Creative Commons Attribution CC BY 


\section{International Journal of Science and Research (IJSR)}

ISSN: 2319-7064

SJIF (2020): 7.803

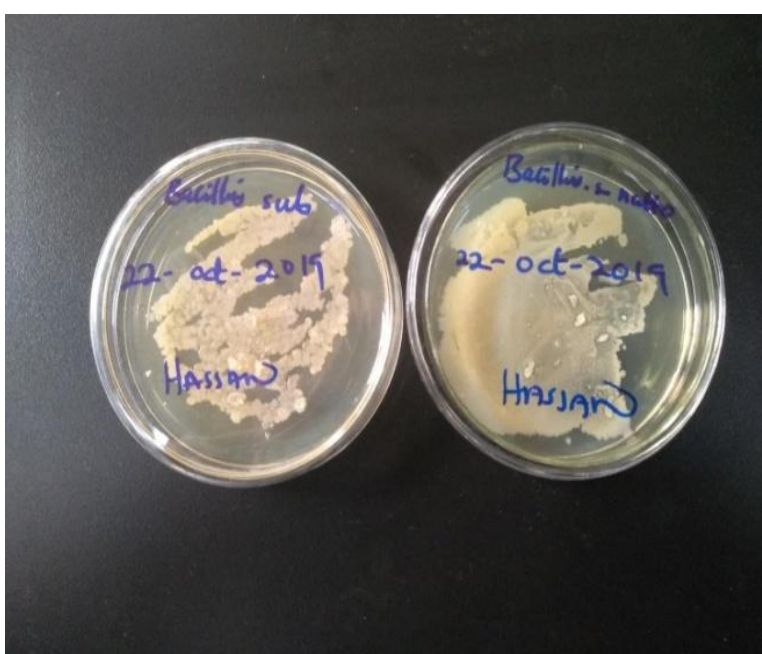

Figure 12.1: Bacillus subtillis

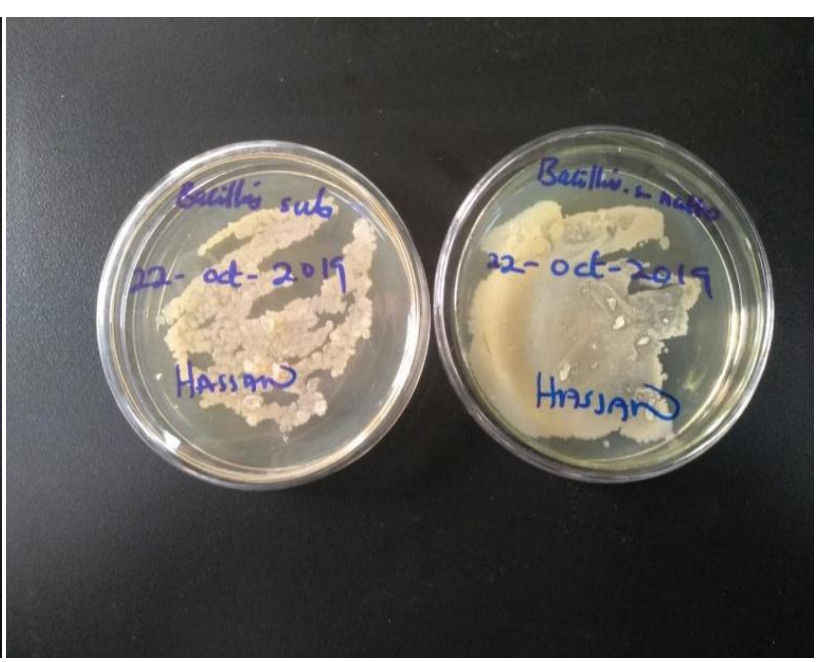

Figure 12.2: Bacillus subtillis natto

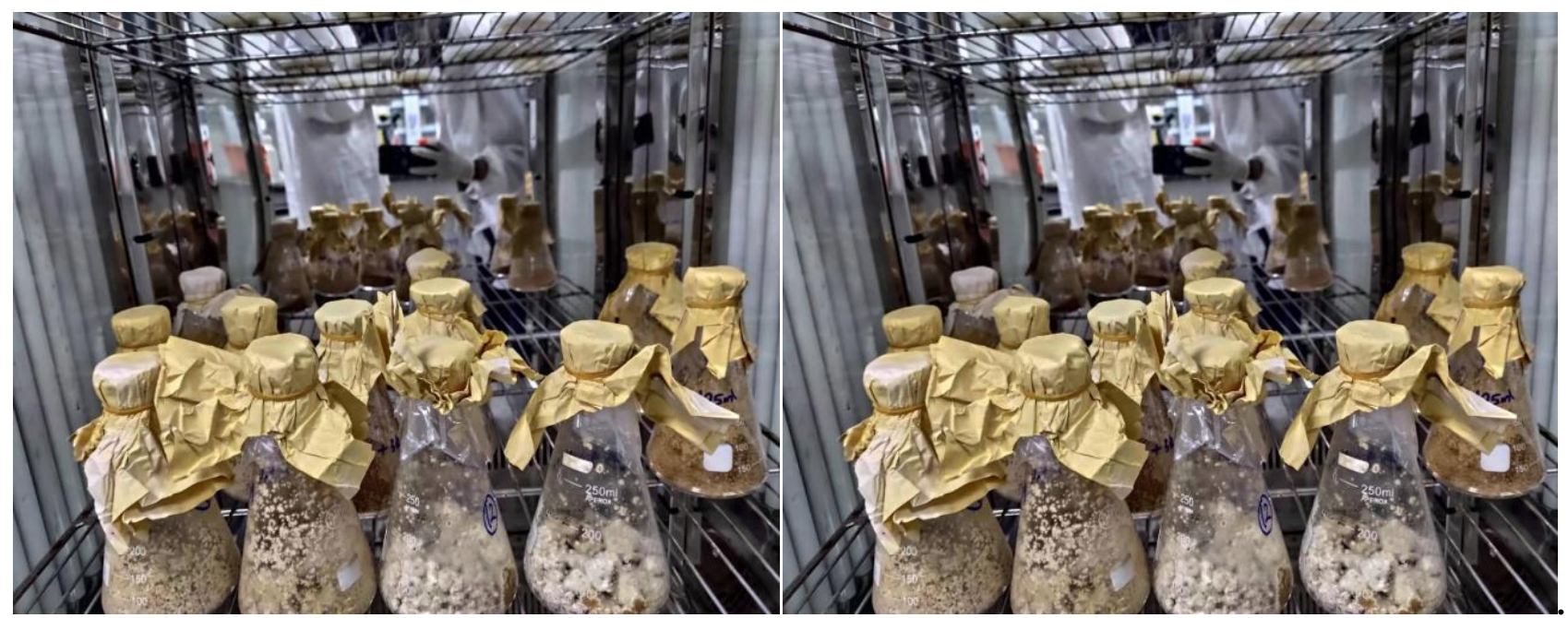

Figure 12.3: Bacteria Cultivation

\section{Co - culture of Bacteria against fungus}

Co - culturing of bacteria \& fungus was made between Bacillus subtillisnatto\&spergillusniger in 4 days of incubating

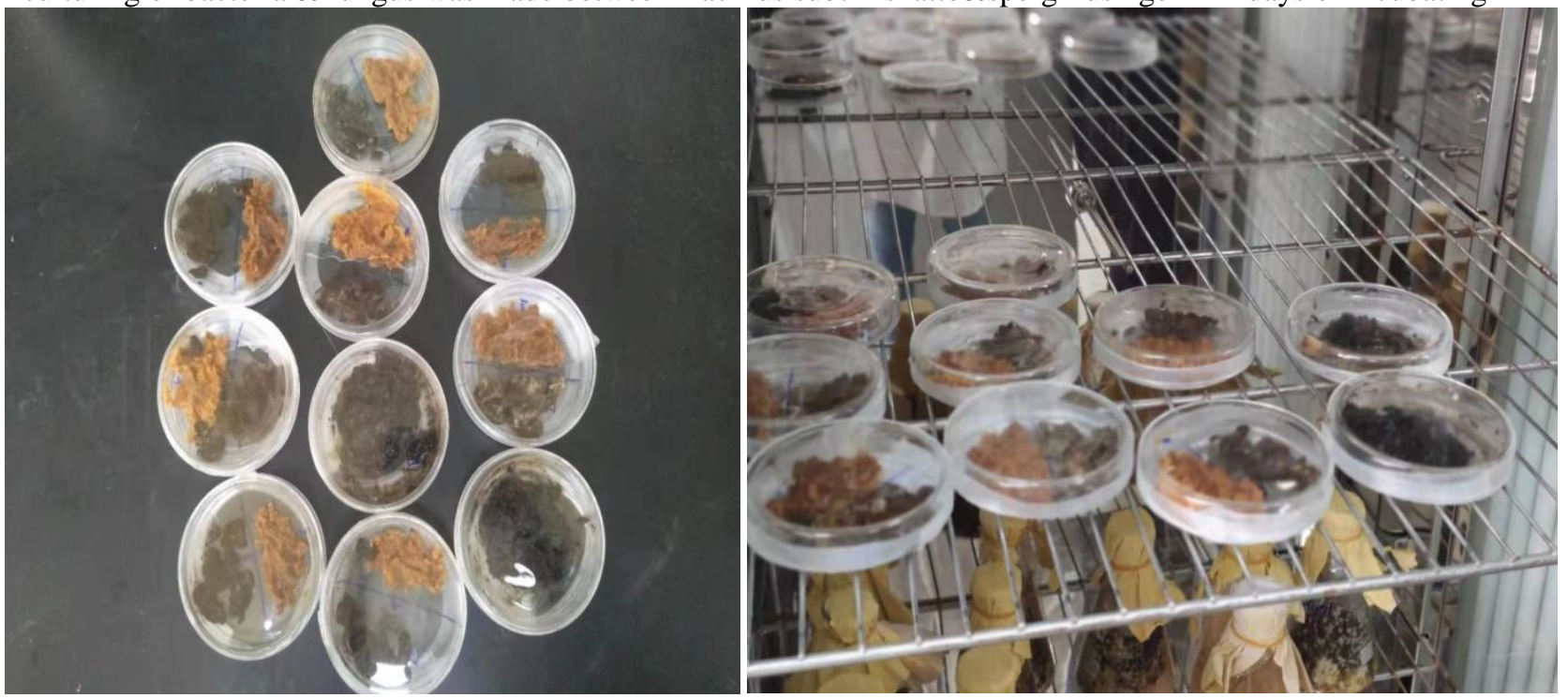

Volume 10 Issue 10, October 2021

www.ijsr.net

Licensed Under Creative Commons Attribution CC BY 


\section{International Journal of Science and Research (IJSR)}

ISSN: 2319-7064

SJIF (2020): 7.803
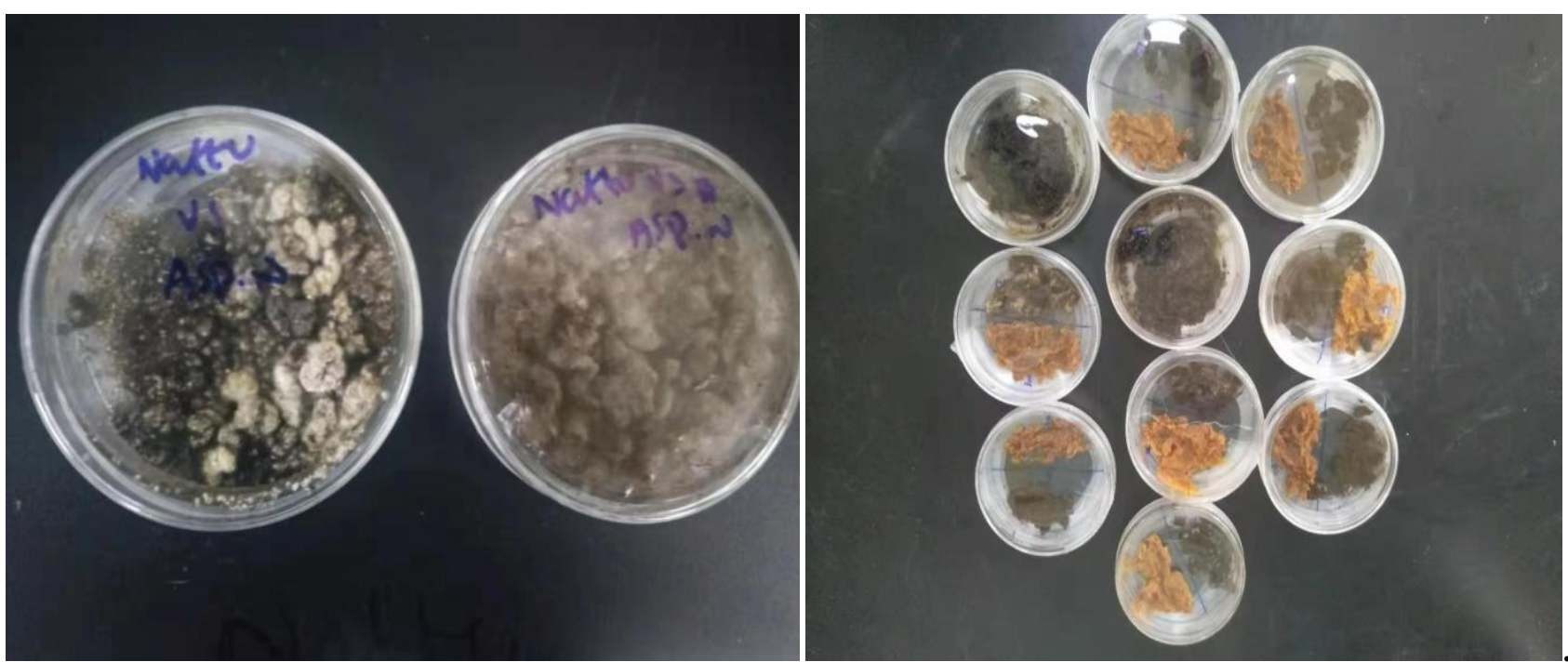

Figure 13: Co - culture of bacteria against fungus

\section{Conclusion}

The use of microbial fermented feed is conductive to improve the nutritional utilization of the feed and enhancing the disease resistance of livestock and its great significance in reducing the use of antibiotics and reducing the cost of breeding Bacillus subtitles natto has more growth than Bacillus subtitles Thespergillusniger has more growth than D. fungus. Gram - negative and Gram - positive bacteria have been extensively studied for production of a variety of antibacterial and antifungal antibiotics, such as: lipopeptide biosurfactants, Surfactin, and fengycin are biosurfactant lipopeptides produced by Bacillus strains. These cyclic lipopeptides produced by Bacillus strains are also used as biocontrol agents for plant disease reduction.

The biosurfactant lipopeptides were purified by using Sephadex LH - 20 column chromatography and the reverse phase HPLC system.

Soybean is a very important feed additive due to many beneficial effects such as better protein digestibility, decreased immunological reactivity as well as boosting the intestinal microbial balance. Soybean undergoes fermentation process to improve nutritional value by altering the nutritive value. The fermentation process utilizes microbials; bacteria or fungi which degrade anti - nutritional factors, increases amount of small sized peptides and improve amino acid contents. Fermented soybean is being used as a probiotic replacing the use of antibiotics which due to prolong use can cause antimicrobial resistance, Soybean is rich in nutrients, it is thought of primarily as protein source but they also contain 30 to $35 \%$ carbohydrates making it as a major source of carbohydrate in the diet. Soybeans provide the amino acids in large quantities which are in limiting amounts in other cereal products. High phosphorous concentration is exhibited by soybean meal and incase of microbial phytase in the diet the phosphorous digestibility is high. Soybean meal can satisfy the entire requirement of amino acid in diets fed to weaning pigs as well as grown pigs.
Fermentation of soybeans using fungi has employed several species of Aspergillus genus like A. niger just to mention a few. Fermentation with Aspergilli has exhibit immerse benefits as completely elimination of phytate, resulting in a protein sourceof feedwith highly available phosphorus as well as zinc, also has enabled carbohydrate breakdown which has been attributed with $\alpha$-galactosidase produced.

Bacterial based fermentation has traditionally utilized Bacillus spp, Fermentation of soybean using B. subtilis results to the fermented soybeans having higher crude protein and lower Trypsin inhibitor content, thus supporting the fact that fermentation process of soybean is indeed complexed process controlled by enzymes and the type of organism selected for the process. Fermentation using bacterial strains results to higher antioxidant leading to increased concentration of Amino Acids such as Histidine, Serine, Valine and Lysine, Bacillus sub is one of the bacterial strain frequently used in soybean fermentation.

Microflora plays a crucial role when it comes to animal nutritive value and disease infections. Probiotics competes with pathogenic bacteria that may be present in the gut for nutrients as well as binding sites on the intestinal epithelium. It tends to use up all the important nutrients starving the pathogenic bacteria hence causing their death. The use of bacterial or fungal strains in the probiotics has also done a fundamental work, for starters this has replace the use of antibiotics which had become very challenging to pig farmers in terms of pig health since prolonged use of antibiotics has made the pigs develop antibacterial resistance as well as the meat being sold to the consumers having allergy to certain types of antibiotics making it even more challenging.

Use of probiotics to improve nutrients ensures good health promote general growth and productivity among animals. Supplement of Bacilli has been reported to increase feed efficiency as well as improved growth rate among the piglets.

The sepration of lipopeptide using column chromatography was done using silica powder and sephdex LH 20 we find that the sephdex LH 20 has been used successfully to seprate

Volume 10 Issue 10, October 2021 www.ijsr.net 
many lipopeptides than silica because sephdex LH 20 seprate many steroids, particularly the unconjugated biologically active ones, sephdex LH 20 gives very low or negligible blank values, and has good sepration temperature result below $25 \mathrm{C}$, after appropriate washing sephdex LH 20 can be re - used many times. while silca can be used one time.

\section{References}

[1] Ajesh K, Sudarslal S, Arunan C, Sreejith K (2013) Kannurin, a novel lipopeptide from Bacillus cereus strain AK1: isolation, structural evaluation and antifungal activities. J ApplMicrobiol 115 (6): 12871296. doi: 10.1111/jam. 12324

[2] Aranda FJ, Teruel JA, Ortiz A (2005) Further aspects on the hemolytic activity of the antibiotic lipopeptideiturin A. BBA - Biomembranes 1713 (1): 51-56. doi: 10.1016/j. bbamem.2005.05.003

[3] Arima K, Kakinuma A, Tamura G (1968) Surfactin, a crystalline peptide lipid surfactant produced by Bacillus subtilis: isolation, characterization and its inhibition of fibrin clot formation. BiochemBiophys Res Commun 31 (3): 488-494. doi: 10.1016/0006 291X (68) 90503 - 2

[4] Banat IM, De Rienzo MA, Quinn GA (2014) Microbial biofilms: biosurfactants as antibiofilm agents. ApplMicrobiolBiotechnol 98 (24): 9915-9929. doi: $10.1007 / \mathrm{s} 00253$ - $014-6169-6$

[5] Besson F, Michel G (1987) Isolation and characterization of new iturins: iturin D and iturin E. J Antibiot 40 (4): 437-442. doi: 10.7164/ antibiotics. 40.437

[6] Byeon SE, Lee YG, Kim BH, Shen T, Lee SY, Park HJ, Park SC, Rhee MH, Cho JY (2008) Surfactin blocks NO production in lipopolysaccharide - activated macrophages by inhibiting NFkappaB activation. J MicrobiolBiotechnol 18 (12): 1984-1989

[7] Cao XH, Wang AH, Wang CL, Mao DZ, Lu MF, Cui YQ, Jiao RZ (2010) Surfactin induces apoptosis in human breast cancer MCF - 7 cells through a ROS/JNK - mediated mitochondrial/caspase pathway. ChemBiol Interact 183 (3): 357-362. doi: 10.1016/j. cbi.2009.11.027

[8] Chen Y, Yan F, Chai Y, Liu H, Kolter R, Losick R, Guo JH (2013) Biocontrol of tomato wilt disease byBacillussubtillus isolates from natural environments depends on conserved genes mediating biofilm formation. Environ Microbiol 15 (3): 848-864. doi: 10.1111/j.1462 - 2920.2012.02860. X

[9] Cho KM, Math RK, Hong SY, Asraful Islam SM, Mandanna DK, Cho JJ, Yun MG, Kim JM, Yun HD (2009) Iturin produced by Bacillus pumilusHY1 from Korean soybean sauce (kanjang) inhibits growth of aflatoxin producing fungi. Food Control 20 (4): 402406. doi: 10.1016/j. foodcont.2008.07.010

[10] Comella N, Grossman AD (2005) Conservation of genes and processes controlled by the quorum response in bacteria: characterization of genes controlled by the quorum - sensing transcription factor ComAinBacillussubtilis. MolMicrobiol 57 (4): 11591174. doi: 10.1111/j.1365 - 2958.2005.04749. x
[11] Coutte F, Leclere V, Bechet M, Guez JS, Lecouturier D, Chollet - Imbert M, Dhulster P, Jacques P (2010) Effect of pps disruption and constitutive expression of srfA on surfactin productivity, spreading and antagonistic properties ofBacillus subtilis168 derivatives. J ApplMicrobiol 109 (2): 480-491. doi: 10.1111/j.1365 - 2672.2010.04683. x

[12] Coutte F, Niehren J, Dhali D, John M, Versari C, Jacques P (2015) Modeling leucine's metabolic pathway and knockout prediction improving the production of surfactin, a biosurfactant from Bacillussubtilis. Biotechnol J 10 (8): 1216-1234. doi: 10.1002/biot.201400541

[13] Das P, Mukherjee S, Sen R (2008) Antimicrobial potential of a lipopeptide biosurfactant derived from a marine Bacillus circulans. J ApplMicrobiol 104 (6): 1675-1184. doi: 10.1111/j.1365 - 2672. 2007.03701. x

[14] Dehghan - Noude G, Housaindokht M, Bazzaz BS (2005) Isolation, characterization, and investigation of surface and hemolytic activities of a lipopeptide biosurfactant produced byBacillussubtilisATCC 6633 . J Microbiol 43 (3): 272-276

[15] Deleu M, Lorent J, Lins L, Brasseur R, Braun N, El Kirat K, Nylander T, Dufrêne YF, Mingeot - Leclercq M - P (2013) Effects of surfactin on membrane models displaying lipid phase separation. BBA Biomembranes 1828 (2): 801-815. doi: 10.1016/j. bbamem.2012.11.007

[16] Deleu M, Paquot M, Nylander T (2005) Fengycin interaction with lipid monolayers at the air - aqueous interface - implications for the effect of fengycin on biological membranes. J Colloid Interface Sci 283 (2): 358-365. doi: 10.1016/j. jcis.2004.09.036

[17] Dey G, Bharti R, Dhanarajan G, Das S, Dey KK, Kumar BN, Sen R, Mandal M (2015) Marine lipopeptideiturin A inhibits Akt mediated GSK3beta and FoxO3a signaling and triggers apoptosis in breast cancer. Sci Rep 5: 10316. doi: 10.1038/srep10316

[18] Gao Z, Zhao X, Lee S, Li J, Liao H, Zhou X, Wu J, Qi G (2013) WH1fungin a surfactincycliclipopeptide is a novel oral immunoadjuvant. Vaccine 31 (26): 27962803. doi: 10.1016/j. vaccine.2013.04.028

[19] GaoZ, ZhaoX, YangT, ShangJ, ShangL, MaiH, QiG (2014) Immunomodulation therapy of diabetes by oral administration of a surfactinlipopeptide in NOD mice. Vaccine 32 (50): 6812-6819. doi: 10.1016/j. vaccine.2014.08.082

[20] Gonzalez - Jaramillo LM, Aranda FJ, Teruel JA, Villegas - Escobar V, Ortiz A (2017) Antimycotic activity of fengycin $\mathrm{C}$ biosurfactant and its interaction with phosphatidylcholine model membranes. Colloids Surf B Biointerfaces 156: 114-122. doi: 10.1016/j. colsurfb.2017.05.021

[21] Gross H, Loper JE (2009) Genomics of secondary metabolite production byPseudomonasspp. Nat Prod Rep 26 (11): 1408-1446. doi: 10.1039/b817075b

[22] Gudiña EJ, Rangarajan V, Sen R, Rodrigues LR (2013) Potential therapeutic applications of biosurfactants. Trends PharmacolSci 34 (12): 667-675. doi: 10.1016/j. tips.2013.10.002

[23] Hajare SN, Subramanian M, Gautam S, Sharma A (2013) Induction of apoptosis in human cancer cells by

Volume 10 Issue 10, October 2021 
aBacilluslipopeptidebacillomycin D. Biochimie 95 (9): 1722-1731. doi: 10.1016/j. biochi.2013.05.015

[24] Han Q, Wu F, Wang X, Qi H, Shi L, Ren A, Liu Q, Zhao M, Tang C (2015) The bacterial lipopeptideiturinsinduce Verticillium dahlia Appl Microbiol Biotechnol cell death by affecting fungal signalling pathways and mediate plant defence responses involved in pathogen - associated molecular pattern - triggered immunity. Environ Microbiol 17 (4): 1166-1188. doi: 10.1111/1462 - 2920.12538

[25] Han Y, Huang X, Cao M, Wang Y (2008) Micellization of surfactin and its effect on the aggregate conformation of amyloid beta (1 - 40). J PhysChem B 112 (47): 15195-15201. doi: 10.1021/jp805966x

[26] Huang X, Lu Z, Zhao H, Bie X, Lü FX, Yang S (2006) Antiviral activity of antimicrobial lipopeptide fromBacillussubtilisfmbjagainstPseudorabies virus, Porcine Parvovirus, Newcastle Disease virus andInfectiousBursal Disease virus in vitro. Int J Pept Res Ther 12 (4): 373-377. doi: 10.1007/s10989 - 006 $9041-4$

[27] Hwang MH, Lim JH, Yun HI, Rhee MH, Cho JY, Hsu WH, Park SC (2005) Surfactin C inhibits the lipopolysaccharide - induced transcription of interleukin - 1beta and inducible nitric oxide synthase and nitric oxide production in murine RAW 264.7 cells. BiotechnolLett 27 (20): 1605-1608. doi: 10.1007/s10529 - 005 - 2515 - 1

[28] Hwang YH, Kim MS, Song IB, Park BK, Lim JH, Park SC, Yun HI (2009) Subacute (28 day) toxicity of surfactin $\mathrm{C}$, a lipopeptide produced byBacillussubtilis, in rats. J Health Sci 55 (3): 351-355. doi: 10.1248/jhs.55.351 Ines M, Dhouha G (2015) Lipopeptide surfactants: production, recovery and pore forming capacity. Peptides 71: 100-112. doi: 10.1016/j. peptides.2015.07.006

[29] Jauregi P, Coutte F, Catiau L, Lecouturier D, Jacques P (2013) Micelle size characterization of lipopeptides produced byB. Subtilisand their recovery by the two step ultrafiltration process. Sep PurifTechnol 104: 175-182. doi: 10.1016/j. seppur.2012.11.017

[30] Jiang C, Shi J, Liu Y, Zhu C (2014) Inhibition of Aspergilluscarbonarius and fungal contamination in table grapes usingBacillussubtilis. Food Control 35 (1): 41-48. doi: 10.1016/j. foodcont.2013.06.054

[31] Jiao S, Li X, Yu HM, Yang H, Li X, Shen ZY (2017) In situ enhancement of surfactin biosynthesis inBacillussubtilisusing novel artificial inducible promoters. BiotechnolBioeng 114 (4): 832-842. doi: 10.1002/bit.26197

[32] Kaneda M, Kajimura Y (2003) New antifungal antibiotics, bacillopeptins and fusaricidins. ChemInform 122 (3): 651-671. doi: 10.1248/ yakushi.122.651

[33] Kikuchi T, Hasumi K (2002) Enhancement of plasminogen activation by surfactin $\mathrm{C}$ : augmentation of fibrinolysis in vitro and in vivo. BBAProteinsProteom 1596 (2): 234-245. doi: 10.1016/S0167 - 4838 (02) 00221 - 2

[34] Kikuchi T, Hasumi K (2003) Enhancement of reciprocal activation of prourokinase and plasminogen by the bacterial lipopeptidesurfactins and iturin Cs. J
Antibiot (Tokyo) 56
10.7164/antibiotics.56.34
$(1)$ :
$34-37$.
doi:

[35] Kim K, Jung SY, Lee DK, Jung JK, Park JK, Kim DK, Lee CH (1998) Suppression of inflammatory responses by surfactin, a selective inhibitor of platelet cytosolic phospholipase A (2). BiochemPharmacol 55 (7): 975985. doi: 10.1016/S0006 - 2952 (97) 00613 - 8

[36] Kim SD, Park SK, Cho JY, Park HJ, Lim JH, Yun HI, Park SC, Lee KY, Kim SK, Rhee MH (2006) Surfactin $\mathrm{C}$ inhibits platelet aggregation. J Pharm Pharmacol 58 (6): 867-870. doi: 10.1211/jpp.58.6.0018

[37] Kim SY, Kim JY, Kim SH, Bae HJ, Yi H, Yoon SH, Koo BS, Kwon M, Cho JY, Lee CE, Hong S (2007) SurfactinfromBacillussubtilis displays anti proliferative effect via apoptosis induction, cell cycle arrest and survival signaling suppression. FEBS Lett 581 (5): 865-871. doi: 10.1016/j. febslet.2007.01.059

[38] Koglin A, Lohr F, Bernhard F, Rogov VV, Frueh DP, Strieter ER, Mofid MR, Guntert P, Wagner G, Walsh CT, Marahiel MA, Dotsch V (2008) Structural basis for the selectivity of the external thioesterase of the surfactinsynthetase. Nature 454 (7206): 907-911. doi: 10.1038/nature07161

[39] Kracht M, Rokos H, Ozel M, Kowall M, Pauli G, Vater J (1999) Antiviral and hemolytic activities of surfactin isoforms and their methyl ester derivatives. J $\begin{array}{llll}\text { Antibiot } & 52 & (7) \text { : 613-619. doi: }\end{array}$ 10.7164/antibiotics.52.613

[40] Lee JH, Nam SH, Seo WT, Yun HD, Hong SY, Kim MK, Cho KM (2012) The production of surfactin during the fermentation ofcheonggukjang by potential probioticBacillus subtilisCSY191 and the resultant growth suppression of MCF - 7 human breast cancer cells. Food Chem 131 (4): 1347-1354. doi: 10.1016/j. foodchem.2011.09.133

[41] Lim JH, Park BK, Kim MS, Hwang MH, Rhee MH, Park SC, Yun HI (2005) The anti - thrombotic activity of surfactins. J Vet Sci 6 (4): 353-355

[42] Maget - Dana R, Peypoux F (1994) Iturins, a special class of pore - forming lipopeptides: biological and physicochemical properties. Toxicology 87 (1-3): 151-174. doi: 10.1016/0300 - 483X (94) 90159 - 7

[43] Meena KR, Kanwar SS (2015) Lipopeptides as the antifungal and antibacterial agents: applications in food safety and therapeutics. Biomed Res Int 2015 (3): 1-9. doi: 10.1155/2015/473050

[44] Mizumoto S, Hirai M, Shoda M (2006) Production of lipopeptide antibiotic iturinA using soybean curd residue cultivated withBacillussubtilis in solid - state fermentation. ApplMicrobiolBiotechnol 72 (5): 869 875. doi: 10.1007/s00253 - 006 - 0389 - 3

[45] Myoungseok K, Jonghwan L, Byungkwon P, Yunhwan H, Song IB, Seungchun P, Yun HI (2009) Effect of surfactin on growth performance of weaning piglets in combination withBacillussubtilis BC1212, vol 26,

[46] Nasir MN, Besson F (2012) Interactions of the antifungal mycosubtilin with ergosterol - containing interfacial monolayers. BBABiomembranes 1818 (5): 1302-1308. doi: 10.1016/j. bbamem.2012.01.020

[47] Ongena M, Jacques P (2008) Bacillus lipopeptides: versatile weapons for plant disease biocontrol. Trends Microbiol 16 (3): 115-125. doi: 10.1016/j. tim.2007.12.009 
[48] Ongena M, Jourdan E, Adam A, Paquot M, Brans A, Joris B, Arpigny JL, Thonart P (2007) Surfactin and fengycinlipopeptidesofBacillus

[49] subtilis as elicitors of induced systemic resistance in plants. Environ Microbiol 9 (4): 1084-1090. doi: 10.1111/j.1462 - 2920.2006.01202. x

[50] Ostroumova OS, Malev VV, Ilin MG, Schagina LV (2010) Surfactin activity depends on the membrane dipole potential. Langmuir 26 (19): 15092-15097. doi: 10.1021/la102691y Palanisamy P, Raichur AM (2008) Biosurfactant mediated synthesis of NiOnanorods. Mater Lett 62 (4-5): 743-746. doi: 10.1016/j. matlet.2007.06.053

[51] Pan H, Zhao X, Gao Z, Qi G (2014) A surfactinlipopeptideadjuvanted hepatitis $B$ vaccines elicit enhanced humoral and cellular immune responses in mice. Protein Peptide Lett 21 (9): 901910. doi: 10.2174/ 0929866521666140418100743

[52] Park SY, Kim JH, Lee SJ, Kim Y (2013a) Involvement of PKA and HO - 1 signaling in anti - inflammatory effects of surfactin in BV - 2 microglial cells. ToxicolApplPharmacol 268 (1): 68-78. doi: 10.1016/j. taap.2013.01.017

[53] Park SY, Kim JH, Lee SJ, Kim Y (2013b) Surfactin exhibits neuroprotective effects by inhibiting amyloid beta - mediated microglial activation. Neurotoxicology 38: 115-123. doi: 10.1016/j. neuro.2013.07.004

[54] Park SY, Kim JH, Lee YJ, Lee SJ, Kim Y (2013c) Surfactin suppresses TPA - induced breast cancer cell invasion through the inhibition of MMP - 9 expression. Int J Oncol 42 (1): 287-296. doi: 10.3892/ijo.2012.1695

[55] Park SY, Kim Y (2009) Surfactin inhibits immunostimulatory function of macrophages through blocking NK - kappaB, MAPK and Akt pathway. IntImmunopharmacol 9 (7-8): 886-893. doi: 10.1016/j. intimp.2009.03.013

[56] Peypoux F, Bonmatin JM, Wallach J (1999) Recent trends in the biochemistry of surfactin. ApplMicrobiolBiot 51 (5): 553-563. doi: 10.1007/s002530051432

[57] ApplMicrobiolBiotechnol Qi G, Zhu F, Du P, Yang X, Qiu D, Yu Z, Chen J, Zhao X (2010)

[58] Lipopeptide induces apoptosis in fungal cells by a mitochondriadependent pathway. Peptides 31 (11): 1978-1986. doi: 10.1016/j.

[59] Peptides.2010.08.003 Rodrigues L, Banat IM, Teixeira J, Oliveira R (2006) Biosurfactants: potential applications in medicine. J AntimicrobChemother 57 (4): 609-618. doi: 10.1093/jac/dk1024

[60] Sahnoun R, Mnif I, Fetoui H, Gdoura R, Chaabouni K, Makni - Ayadi F, Kallel C, Ellouze - Chaabouni S, Ghribi D (2014) Evaluation of Bacillus subtilisSPB1 lipopeptidebiosurfactant toxicity towards mice. Int J Pept Res Ther 20 (3): 333-340. doi: 10.1007/s10989 014 - 9400 - 5

[61] Schneider J, Taraz K, Budzikiewicz H, Deleu M, Thonart P, Jacques P (2012) The structure of two fengycinsfrom Bacillus subtilisS499. Z Naturforsch C 54 (11): 859-865. doi: 10.1515/znc - 1999 - 1102

[62] Stein T (2005) Bacillussubtilisantibiotics: structures, syntheses and specific functions. MolMicrobiol 56 (4): 845-857. doi: 10.1111/j.1365 - 2958.2005.04587. x
Tang Q, Bie X, Lu Z, Lv F, Tao Y, Qu X (2014) Effects of fengycin from Bacillus subtilisfmbJ on apoptosis and necrosis in Rhizopusstolonifer. J Microbiol 52 (8): 675-680. doi: 10.1007/s12275 - 014 $-3605-3$

[63] Vollenbroich D, Ozel M, Vater J, Kamp RM, Pauli G (1997) Mechanism of inactivation of enveloped viruses by the biosurfactantsurfactinfromBacillussubtilis. Biologicals $25 \quad$ (3): 289-297. doi: 10.1006/biol.1997.0099

[64] Wang X, Hu W, Zhu L, Yang Q (2017) Bacillussubtilisandsurfactin inhibit the transmissible gastroenteritis virus from entering the intestinal epithelial cells. Biosci Rep 37 (2): BSR20170082. doi: $10.1042 /$ bsr20170082

[65] Xu HM, Rong YJ, Zhao MX, Song B, Chi ZM (2014) Antibacterial activity of the lipopetides produced byBacillusamyloliquefaciens M1 against multidrug resistantVibriospp. isolated from diseased marine animals. ApplMicrobiolBiotechnol 98 (1): 127-136. doi: 10.1007/s00253 - 013 - 5291 - 1

[66] Yin HP, Guo CL, Wang Y, Liu D, Lv YB, Lv FX, Lu ZX (2013) Fengycin inhibits the growth of the human lung cancer cell line 95D through reactive oxygen species production and mitochondria - dependent apoptosis. Anti - Cancer Drug 24 (6): 587-598. doi: 10.1097/CAD.0b013e3283611395

[67] Zeriouh H, Romero D, Garcia - Gutierrez L, Cazorla FM, de Vicente A, Perez - Garcia A (2011) The iturin like lipopeptides are essential components in the biological control arsenal ofBacillussubtilis against bacterial diseases of cucurbits. Mol Plant - Microbe Interact 24 (12): 1540-1552. doi: 10.1094/MPMI - 06 $11-0162$

[68] Zhang B, Dong C, Shang Q, Han Y, Li P (2013) New insights into membrane - active action in plasma membrane of fungal hyphae by the lipopeptide antibiotic bacillomycin L. BBA - Biomembranes 1828 (9): 2230-2237. doi: 10.1016/j. bbamem.2013.05.033

[69] Zhang L, Xing X, Ding J, Zhao X, Qi G (2017) Surfactin variants for intra - intestinal delivery of insulin. Eur J Pharm Biopharm 115: 218- 228. doi: 10.1016/j. ejpb.2017.03.005

[70] Zhang Y, Liu C, Dong B, Ma X, Hou L, Cao X, Wang C (2015) Anti - inflammatory activity and mechanism of surfactin in lipopolysaccharide - activated macrophages. Inflammation 38 (2): 756-764. doi: $10.1007 / \mathrm{s} 10753$ - 014 - 9986 - y

[71] Zhu Z, Zhang G, Luo Y, Ran W, Shen Q (2012) Production of lipopeptides by Bacillus amyloliquefaciensXZ - 173 in solid state fermentation using soybean flour and rice straw as the substrate. BioresourTechnol 112: 254-260. doi: 10.1016/j. biortech.2012.02.057

\section{Volume 10 Issue 10, October 2021 www.ijsr.net}

